\title{
Across the great divide: a literature review of management accounting and operations management at the shop floor
}

\author{
Amanda Curry ${ }^{1}$ \\ Received: 12 January 2017 / Accepted: 22 August 2018 / Published online: 30 August 2018 \\ (c) The Author(s) 2018
}

\begin{abstract}
Management accounting's ability to provide relevant information in production environments has long been discussed in the fields of management accounting (MA) and operations management (OM). Researchers from each field play a major part not only in disseminating their research results, but also in channelling their perceptions of management accounting in production environments through journal publications. The thesis of this paper is that via an examination of the paradigms, theories, and methods in the fields of MA and OM our understanding of the prevailing assumptions about management accounting in production environments in the academic community can be enhanced. The review shows a divide between the fields where the field of OM is oriented towards problem-solving, and the field of MA is more theory oriented. The review points out that the understanding of practice is a divider between the fields, but it also suggests that incorporation of practicing production members into research is a promising path forward. The paper then concludes that OM problematizes management accounting in production environments as a starting point for their research agenda and that both fields portrayal of management accounting in production environments need to be nuanced. There is a need to challenge the research expectations and to accept unconventional research methods to enhance knowledge about management accounting in production environments.
\end{abstract}

Keywords Management accounting · Operations management · Paradigm · Method · Theory

\section{JEL Classification M1}

Amanda Curry

amanda.curry@1tu.se

1 Department of Business and Administration, Technology and Social Sciences, Accounting and Control, Luleå University of Technology, Luleå, Sweden 


\section{Introduction}

Management accounting's ability to provide relevant information in production environments has long been discussed in the fields of management accounting (MA) and operations management (OM). One early criticism from the field of MA was the loss of relevance in management accounting for production environments (Johnson and Kaplan 1987), perhaps due to technical flaws in the design of the accounting system (Macintosh 1994, p. 209). Similarly, OM researchers have questioned whether management accounting is excessive in production environments (Hansen and Mouritsen 2006). Skinner (1986, p. 44) described the typical management accounting system as "...pathetically old-fashioned and ineffective" where attempts to decrease costs instead would increase them.

Some of the main flaws in management accounting for production environments that often are elevated from researchers in the fields of MA and OM seem to be the historical (often financial) connotation of management accounting, the detached nature of managing operations from a distance, and the lack of answers of what to do, and how (Hansen and Mouritsen 2007; Otley 1999). Management accounting is thus described as unsuitable in production environments and potentially harmful for operations. In this way, management accounting seems to be expressed as having (at best) an instrumental part to play in production environments.

Operations management, on the other hand, is often characterized in terms of proactivity, providing hands-on techniques and best practices (Bourne et al. 2003; De Lange-Ros and Boer 2001; Radnor and Barnes 2007). Practices such as Just-in-time (JIT), Lean production, and Total Quality Management (TQM) have been developed and provided by the field of OM. When it comes to management accounting and operations, Maskell (2000) suggests lean accounting as a solution to the shortcomings, whilst others highlight the potential of management accounting for control, communication and improvements of operations if it is proactively designed and managed (Melnyk et al. 2004).

To a notable extent, the field of MA seems to accept the criticism from the OM field of management accounting in production environments. Some of the criticism is met by MA researchers by adapting management accounting techniques to better support operations in production environments (e.g. activity-based costing, performance management systems). Other MA researchers simply tend to admit to the lack of practical relevance as a main flaw (Jönsson 1998; Hall 2010).

Thus, the fields of MA and OM seem to be conducting their own separate lines of research in search for redemption to the criticism management accounting in production environments has been facing. At the same time, the fields are connected not the least in practice (Lowe and Koh 2007; Miller and O'Leary 1993). With the notable exception of Hansen and Mouritsen (2007) there are few researchers who acknowledge that the fields of MA and OM are interrelated and have the potential to learn from each other. Researchers from each field then play a major part not only in disseminating their research results, but also in channeling their perceptions of management accounting in production environments through journal publications. The journal publications have an impact on their audiences and on their prevailing norms, where the shortcoming of management 
accounting in production environments risks becoming taken-for-granted assumptions.

In contrast to this scenario, the thesis of this paper is that an examination of the paradigms, theories, and methods in the fields of MA and OM can enhance our understanding of the prevailing assumptions about management accounting in production environments in the academic community. To the researcher's knowledge, reviews addressing the magnitude and characteristics of the prevailing assumptions within the fields MA and OM are scarce. Understanding the interface between the fields can pinpoint differences and similarities within the fields' research assumptions, thereby highlighting researchers' perceptions of management accounting in production environments (Bhimani 1994; Bromwich and Bhimani 1989). Unless we examine the interface between the fields of MA and OM we may fail to test and challenge the underlying assumptions, thereby rendering research on management accounting in production environments unreliable (Lukka and Mouritsen 2002).

The purpose of this literature review is to explore the presentation of management accounting in production environments in the academic community by (1) identifying the key underlying assumptions within the MA and OM literature, (2) analyzing the magnitude and characteristics of how those assumptions are manifested in the field of MA and OM, and (3) offering avenues for inquiry that need to be addressed.

The contributions of this paper are to provide the extant literature with a comparative overview of prevailing research assumptions regarding management accounting in production environments within the fields of MA and OM and to offer research paths forward that may bring progress for knowledge creation concerning management accounting in production environments.

The next section describes how the review was conducted in terms of identifying literature and developing a classification scheme. Thereafter, the paradigms, theories and methods identified in the MA and OM literature are presented. Following this, a discussion of the underlying research assumptions within the field of MA and OM is provided. Lastly, three complementary conclusions are provided together with paths forward.

\section{The approach to the literature}

The following sections describe the literature search process, the development of a classification scheme, and the process of analyzing articles.

\subsection{The initial three steps}

The literature review builds on Hart's (1998) ideas of how to conduct a systematic review of the literature to find differences and similarities by identifying the ideas expressed in the literature from the two research fields. This systematic approach provides basis for researchers to challenge taken-for-granted knowledge within research fields (Fisch and Block 2018). Systematic literature reviews may be used to address conceptual intersection (e.g. Graf-Vlachy et al. 2018) but also to address intersections 
Table 1 Selected journals and distribution of articles in each journal

\begin{tabular}{|c|c|}
\hline Operations management journals & Number of articles \\
\hline Intl. J. of operations and production management & 2 \\
\hline J. of operations management & 3 \\
\hline Intl. J. of production economics & 9 \\
\hline Production and operations management & 5 \\
\hline Intl. J. of production research & 5 \\
\hline Production planning and control & 3 \\
\hline Total number of articles & 27 \\
\hline Management accounting journals & Number of articles \\
\hline J. of accounting research & 1 \\
\hline Accounting review & 2 \\
\hline Accounting, organizations and society & 4 \\
\hline Critical perspectives on accounting & 4 \\
\hline British accounting review & 2 \\
\hline Management accounting research & 10 \\
\hline Contemporary accounting research & 1 \\
\hline Abacus & 1 \\
\hline Accounting and business research & 1 \\
\hline Accounting forum & 1 \\
\hline Accounting, auditing and accountability journal & 3 \\
\hline J. of accounting and public policy & 1 \\
\hline J. of accounting and economics & 1 \\
\hline Total number of articles & 32 \\
\hline
\end{tabular}

between fields (Block et al. 2017). The intention was to use the highest ranked journals within MA research and the highest ranked journals within OM to find the journals that have the highest impact on prevailing research norms. ${ }^{1}$ To identify the highest ranked journals, the fourth version of the academic journal quality guide published by the Association of Business Schools (ABS) of 2014 was used, with journals receiving one of the two highest grades being included in the first selection (see Table 1). The first step was to locate relevant articles using the Ebsco database during October 2014. The search words were derived from the purpose of the present review (Hart 1998, p. 172). The same search words were used for the journals in both fields. The search words were "management accounting" and "shop floor" or "production environment" or "operational level*"; they generated 32 articles in MA journals and 27 in OM journals (see Table 1 for distribution).

Table 1 shows the journals selected within each research field and the initial number of articles identified within each journal. The second step was to review the abstract of the generated articles. By considering the title and reading the abstract, the search

\footnotetext{
1 Note that this choice may not reflect the complete fields of MA and OM.
} 
result was narrowed down to exclude 5 articles from OM journals and 11 from MA journals. Articles regarding external pricing and purchasing aspects and carbon dioxide emissions in production processes were excluded from the OM literature and articles regarding the bank sector, taxation, university sector, and auditing were excluded from the MA literature since neither concerns the production process. Further exclusion of articles was determined in dialogue with colleagues after reading the articles, resulting in exclusion of two MA articles and four OM articles. Examples of exclusion are Woo et al. (2008) and H'Mida and Vernadat (2009), who targeted the design and development of new products, which was outside the scope of this study.

After exclusion of articles as presented in Table 2, the third step was to carefully review the articles. The MA articles were read first since that was the primary audience and the author's research field. Thereafter, the same procedure was followed with the $\mathrm{OM}$ articles. The articles were read in chronological order.

Table 2 shows the identified articles in chronological order. The articles excluded are shown in the column to the right with a note for the reason for exclusion.

\subsection{Classification scheme}

After article collection, a classification scheme was developed to obtain an overview of the information retrieved from the literature (Hart 1998, p. 144). The categories used in the classification were both derived from the literature and developed during the reviewing process. Three main classifications were made based upon the choices made by the researcher of the articles. These are paradigms, theories, and methods. The classification scheme followed these three main classifications and included subclassifications from the literature or inductively derived during the review process.

\subsubsection{Paradigm classifications}

Paradigm classifications were based on Burrell and Morgan's (1979) matrix of assumptions about the nature of social science (objectivism versus subjectivism) and the nature of society (regulation versus radical change). Objectivism is characterized by deterministic assumptions, whereas interpretative assumptions characterize subjectivism. Paradigms are considered strong phenomena that do not easily allow researchers to move between them (Malmi 2010) and often create areas of normalcy (Lukka and Mouritsen 2002). Introverted dialogues may be the results of not speaking to audiences outside one's comfort paradigm (Burrell and Morgan 1979, p. 22). Therefore, this was considered as a first classification to address underlying assumptions of management accounting in production environments.

Burrell and Morgan's matrix has been criticized due to its categorical nature (c.f. Roberts and Scapens 1985). However, to review the articles, some categorization was necessary, and paradigms can be considered to capture the dominant meta-theoretical assumptions. Nonetheless, they should not be seen as mutually exclusive (Ahrens 2008). Paradigm classification enables the researchers to analyze similarities and differences and has been applied in previous literature reviews focusing on research approaches (Schmidt and Günther 2016). The sorting was based on the assumption 
Table 2 Article search results

\begin{tabular}{|c|c|c|c|}
\hline Identity number & Publication year & OM articles & Excluded due to \\
\hline 1 & 1991 & $\begin{array}{l}\text { Bakke, N. A., \& Hellberg, R. (1991). } \\
\text { Relevance lost? A critical discussion of } \\
\text { different cost accounting principles in } \\
\text { connection with decision making for } \\
\text { both short and long term production } \\
\text { scheduling. International Journal of } \\
\text { Production Economics }\end{array}$ & \\
\hline 2 & 1991 & $\begin{array}{l}\text { Datar, S., Kekre, S., Mukhopadyay, T., \& } \\
\text { Svaan, E. (1991). Overloaded } \\
\text { overheads: Activity-based cost analysis } \\
\text { of material handling in cell } \\
\text { manufacturing. Journal of Operations } \\
\text { Management }\end{array}$ & \\
\hline
\end{tabular}

Handfield, R. B. (1993). A resource dependence perspective of just-in-time purchasing. Journal of Operations Management

Bhimani, A. (1994). Modern cost management: Putting the organization before the technique. International Journal of Production Economics

Corbey, M. (1994). On the availability of "relevant costs" information in operations management. International Journal of Production Economics

Chang, D., \& Lee, S. M. (1996). The impact of critical success factors of JIT implementation on organizational performance. Production Planning and Control

Ghalayini, A. M., Noble, J. S., \& Crowe, T. J. (1997). An integrated dynamic performance measurement system for improving manufacturing competitiveness. International Journal of Production Economics

Tayles, M., \& Walley, P. (1997). Integrating manufacturing and management accounting strategy: Case study insights. International Journal of Production Economics

Order review/release in the absence of adherence to formal scheduling policies. Journal of Operations Management 
Table 2 continued

\begin{tabular}{|c|c|c|c|}
\hline Identity number & Publication year & OM articles & Excluded due to \\
\hline 10 & 1999 & $\begin{array}{l}\text { Spedding, T. A., \& Sun, G. Q. (1999). } \\
\text { Application of discrete event } \\
\text { simulation to the activity based costing } \\
\text { of manufacturing systems. } \\
\text { International Journal of Production } \\
\text { Economics }\end{array}$ & \\
\hline 11 & 2000 & $\begin{array}{l}\text { Busby, J. S., \& Williamson, A. (2000). } \\
\text { The appropriate use of performance } \\
\text { measurement in non-production } \\
\text { activity: The case of engineering } \\
\text { design. International Journal of } \\
\text { Operations and Production } \\
\text { Management }\end{array}$ & $\begin{array}{l}\text { Product development } \\
\text { phase }\end{array}$ \\
\hline 12 & 2005 & $\begin{array}{l}\text { Kirche, E., \& Srivastava, R. (2005). An } \\
\text { ABC-based cost model with inventory } \\
\text { and order level costs: A comparison } \\
\text { with TOC. International Journal of } \\
\text { Production Research }\end{array}$ & \\
\hline 13 & 2006 & $\begin{array}{l}\text { Stevenson, M., \& Hendry, L. C. (2006). } \\
\text { Aggregate load-oriented workload } \\
\text { control: A review and a } \\
\text { re-classification of a key approach. } \\
\text { International Journal of Production } \\
\text { Economics }\end{array}$ & $\begin{array}{l}\text { Not addressing } \\
\text { accounting }\end{array}$ \\
\hline 14 & 2006 & $\begin{array}{l}\text { Umble, M., Umble, E., \& Murakami, S. } \\
\text { (2006). Implementing theory of } \\
\text { constraints in a traditional japanese } \\
\text { manufacturing environment: The case } \\
\text { of hitachi tool engineering. } \\
\text { International Journal of Production } \\
\text { Research }\end{array}$ & Implementation of TOC \\
\hline 15 & 2007 & $\begin{array}{l}\text { Bendoly, E., Rosenzweig, E. D., \& } \\
\text { Stratman, J. K. (2007). Performance } \\
\text { metric portfolios: A framework and } \\
\text { empirical analysis. Production and } \\
\text { Operations Management }\end{array}$ & \\
\hline 16 & 2008 & $\begin{array}{l}\text { Chen, C.-C. (2008). An } \\
\text { objective-oriented and } \\
\text { product-line-based manufacturing } \\
\text { performance measurement. } \\
\text { International Journal of Production } \\
\text { Economics }\end{array}$ & \\
\hline 17 & 2008 & $\begin{array}{l}\text { Sarmah, S. P., Acharya, D., \& Goyal, S. } \\
\text { K. (2008). Coordination of a } \\
\text { single-manufacturer/multi-buyer } \\
\text { supply chain with credit option. } \\
\text { International Journal of Production } \\
\text { Economics }\end{array}$ & Supply chain \\
\hline
\end{tabular}


Table 2 continued

\begin{tabular}{|c|c|c|c|}
\hline Identity number & Publication year & OM articles & Excluded due to \\
\hline 18 & 2008 & $\begin{array}{l}\text { Woo, J., Kulvatunyou, B., \& Cho, H. } \\
\text { (2008). Allocation of manufacturers } \\
\text { through internet-based collaboration } \\
\text { for distributed process planning. } \\
\text { International Journal of Production } \\
\text { Research }\end{array}$ & $\begin{array}{l}\text { Design and planning } \\
\text { phase }\end{array}$ \\
\hline 19 & 2009 & $\begin{array}{l}\text { Hall, J. M., Kopalle, P. K., \& Pyke, D. F. } \\
\text { (2009). Static and dynamic pricing of } \\
\text { excess capacity in a make-to-order } \\
\text { environment. Production and } \\
\text { Operations Management }\end{array}$ & Pricing \\
\hline 20 & 2009 & $\begin{array}{l}\text { H'Mida, F., \& Vernadat, F. (2009). A } \\
\text { constraint approach (flexible CSP) for } \\
\text { alternative cost estimation of a } \\
\text { mechanical product. International } \\
\text { Journal of Production Research }\end{array}$ & $\begin{array}{l}\text { Design process and } \\
\text { product development }\end{array}$ \\
\hline 21 & 2011 & $\begin{array}{l}\text { Filomena, T. P., Anzanello, M. J., Neto, } \\
\text { F. J. K., Duffey, M., \& Campos-Nanez, } \\
\text { E. (2011). Manufacturing } \\
\text { feature-based cost management } \\
\text { system: A case study in brazil. } \\
\text { Production Planning and Control }\end{array}$ & \\
\hline 22 & 2012 & $\begin{array}{l}\text { Jabali, O., Van Woensel, T., \& De Kok, } \\
\text { A. G. (2012). Analysis of travel times } \\
\text { and CO } 2 \text { emissions in time-dependent } \\
\text { vehicle routing. Production and } \\
\text { Operations Management }\end{array}$ & $\begin{array}{l}\text { Transportation and CO2 } \\
\text { emissions }\end{array}$ \\
\hline 23 & 2012 & $\begin{array}{l}\text { Ortega, C. H., Garrido-Vega, P., \& } \\
\text { Machuca, J. A. D. (2012). Analysis of } \\
\text { interaction fit between manufacturing } \\
\text { strategy and technology management } \\
\text { and its impact on performance. } \\
\text { International Journal of Operations } \\
\text { and Production Management }\end{array}$ & \\
\hline 24 & 2012 & $\begin{array}{l}\text { Paksoy, T., Özceylan, E., \& Gökçen, H. } \\
\text { (2012). Supply chain optimisation with } \\
\text { assembly line balancing. International } \\
\text { Journal of Production Research }\end{array}$ & \\
\hline 25 & 2013 & $\begin{array}{l}\text { Arya, A., Gong, N., \& Ramanan, R. N. } \\
\text { (2014). Quality testing and product } \\
\text { rationing by input suppliers. } \\
\text { Production and Operations } \\
\text { Management, }\end{array}$ & \\
\hline 26 & 2013 & $\begin{array}{l}\text { Shan, J., \& Zhu, K. (2013). Inventory } \\
\text { management in china: An empirical } \\
\text { study. Production and Operations } \\
\text { Management }\end{array}$ & \\
\hline
\end{tabular}


Table 2 continued

\begin{tabular}{|c|c|c|c|}
\hline Identity number & Publication year & OM articles & Excluded due to \\
\hline 27 & 2014 & $\begin{array}{l}\text { Darlington, J., Francis, M., Found, P., \& } \\
\text { Thomas, A. (2015). Design and } \\
\text { implementation of a drum-buffer-rope } \\
\text { pull-system.Production Planning and } \\
\text { Control }\end{array}$ & \\
\hline
\end{tabular}

\begin{tabular}{|c|c|c|c|}
\hline & Publication year & MA articles & Excluded due to \\
\hline 28 & 1985 & $\begin{array}{l}\text { Berry, A. J., Capps, T., Cooper, D., } \\
\text { Ferguson, P., Hopper, T., \& Lowe, E. A. } \\
\text { (1985). Management control in an area } \\
\text { of the NCB: Rationales of accounting } \\
\text { practices in a public enterprise. } \\
\text { Accounting, Organizations and Society }\end{array}$ & \\
\hline 29 & 1988 & $\begin{array}{l}\text { Banker, R. D., Datar, S. M., \& Kekre, S. } \\
\text { (1988). Relevant costs, congestion and } \\
\text { stochasticity in production } \\
\text { environments. Journal of Accounting } \\
\text { and Economics }\end{array}$ & \\
\hline 30 & 1994 & $\begin{array}{l}\text { Hoque, Z., \& Hopper, T. (1994). } \\
\text { Rationality, accounting and politics: A } \\
\text { case study of management control in a } \\
\text { bangladeshi jute mill. Management } \\
\text { Accounting Research }\end{array}$ & \\
\hline 31 & 1999 & $\begin{array}{l}\text { Arnold, P. J. (1999). From the union hall: } \\
\text { A labor critique of the new } \\
\text { manufacturing and accounting regimes. } \\
\text { Critical Perspectives on Accounting }\end{array}$ & \\
\hline 32 & 1999 & $\begin{array}{l}\text { Jazayeri, M., \& Hopper, T. (1999). } \\
\text { Management accounting within world } \\
\text { class manufacturing: A case study. } \\
\text { Management Accounting Research }\end{array}$ & \\
\hline 33 & 2000 & $\begin{array}{l}\text { Mia, L. (2000). Just-in-time } \\
\text { manufacturing, management } \\
\text { accounting systems and profitability. } \\
\text { Accounting and Business Research }\end{array}$ & \\
\hline 34 & 2000 & $\begin{array}{l}\text { Reid, G. C., \& Smith, J. A. (2000). The } \\
\text { impact of contingencies on } \\
\text { management accounting system } \\
\text { development. Management Accounting } \\
\text { Research }\end{array}$ & \\
\hline 35 & 2001 & $\begin{array}{l}\text { Emsley, D. (2001). Redesigning variance } \\
\text { analysis for problem solving. } \\
\text { Management Accounting Research }\end{array}$ & \\
\hline 36 & 2001 & $\begin{array}{l}\text { Uddin, S., \& Hopper, T. (2001). A } \\
\text { bangladesh soap opera: Privatisation, } \\
\text { accounting, and regimes of control in a } \\
\text { less developed country. Accounting, } \\
\text { Organizations and Society }\end{array}$ & \\
\hline
\end{tabular}


Table 2 continued

\begin{tabular}{|c|c|c|c|}
\hline & Publication year & MA articles & Excluded due to \\
\hline 37 & 2002 & $\begin{array}{l}\text { Lin, Z. J., \& Yu, Z. (2002). } \\
\text { Responsibility cost control system in } \\
\text { china: A case of management } \\
\text { accounting application. Management } \\
\text { Accounting Research }\end{array}$ & \\
\hline 38 & 2004 & $\begin{array}{l}\text { Gordon, E. A., \& Joos, P. R. (2004). } \\
\text { Unrecognized deferred taxes: Evidence } \\
\text { from the U.K. Accounting Review }\end{array}$ & $\begin{array}{r}\text { Not production } \\
\text { environments }\end{array}$ \\
\hline 39 & 2005 & $\begin{array}{l}\text { Abernethy, M. A., \& Bouwens, J. (2005). } \\
\text { Determinants of accounting innovation } \\
\text { implementation. Abacus }\end{array}$ & \\
\hline 40 & 2005 & $\begin{array}{l}\text { Abernethy, M. A., Horne, M., Lillis, A. } \\
\text { M., Malina, M. A., \& Selto, F. H. } \\
\text { (2005). A multi-method approach to } \\
\text { building causal performance maps } \\
\text { from expert knowledge. Management } \\
\text { Accounting Research }\end{array}$ & \\
\hline 41 & 2006 & $\begin{array}{l}\text { Tan, H., \& Jamal, K. (2006). Effect of } \\
\text { accounting discretion on ability of } \\
\text { managers to smooth earnings. Journal } \\
\text { of Accounting and Public Policy }\end{array}$ & $\begin{array}{l}\text { External } \\
\text { communication }\end{array}$ \\
\hline 42 & 2007 & $\begin{array}{l}\text { Ahrens, T., \& Mollona, M. (2007). } \\
\text { Organisational control as cultural } \\
\text { practice-A shop floor ethnography of a } \\
\text { sheffield steel mill. Accounting, } \\
\text { Organizations and Society }\end{array}$ & \\
\hline 43 & 2007 & $\begin{array}{l}\text { Al-Omiri, M., \& Drury, C. (2007). A } \\
\text { survey of factors influencing the choice } \\
\text { of product costing systems in UK } \\
\text { organizations. Management } \\
\text { Accounting Research }\end{array}$ & \\
\hline 44 & 2007 & $\begin{array}{l}\text { Emsley, D., \& Kidon, F. (2007). The } \\
\text { relationship between trust and control } \\
\text { in international joint ventures: } \\
\text { Evidence from the airline industry. } \\
\text { Contemporary Accounting Research }\end{array}$ & Joint ventures \\
\hline 45 & 2007 & $\begin{array}{l}\text { Lowe, A., \& Koh, B. (2007). Inscribing } \\
\text { the organization: Representations in } \\
\text { dispute between accounting and } \\
\text { production. Critical Perspectives on } \\
\text { Accounting }\end{array}$ & \\
\hline 46 & 2008 & $\begin{array}{l}\text { Armstrong, P. (2008). Calling out for } \\
\text { more: Comment on the future of } \\
\text { interpretive accounting research. } \\
\text { Critical Perspectives on Accounting }\end{array}$ & $\begin{array}{c}\text { Not production } \\
\text { environment }\end{array}$ \\
\hline
\end{tabular}


Table 2 continued

\begin{tabular}{|c|c|c|c|}
\hline & Publication year & MA articles & Excluded due to \\
\hline 47 & 2008 & $\begin{array}{l}\text { Kobelsky, K. W., Richardson, V. J., } \\
\text { Smith, R. E., \& Zmud, R. W. (2008). } \\
\text { Determinants and consequences of } \\
\text { firm information technology budgets. } \\
\text { Accounting Review }\end{array}$ & $\begin{array}{c}\text { Not production } \\
\text { environment }\end{array}$ \\
\hline 48 & 2008 & $\begin{array}{l}\text { Moilanen, S. (2008). The role of } \\
\text { accounting and an intermediate } \\
\text { subsidiary in the management control } \\
\text { system. Management Accounting } \\
\text { Research }\end{array}$ & $\begin{array}{c}\text { Not production } \\
\text { environment }\end{array}$ \\
\hline 49 & 2008 & $\begin{array}{l}\text { Sandelin, M. (2008). Operation of } \\
\text { management control practices as a } \\
\text { package-A case study on control } \\
\text { system variety in a growth firm context. } \\
\text { Management Accounting Research }\end{array}$ & $\begin{array}{c}\text { Not production } \\
\text { environment }\end{array}$ \\
\hline 50 & 2009 & $\begin{array}{l}\text { Archel, P., Husillos, J., Larrinaga, C., \& } \\
\text { Spence, C. (2009). Social disclosure, } \\
\text { legitimacy theory and the role of the } \\
\text { state. Accounting, Auditing and } \\
\text { Accountability Journal }\end{array}$ & \\
\hline 51 & 2009 & $\begin{array}{l}\text { McLean, T. (2009). The measurement } \\
\text { and management of human } \\
\text { performance in seventeenth century } \\
\text { English farming: The case of henry } \\
\text { best. Accounting Forum }\end{array}$ & $\begin{array}{c}\text { Not production } \\
\text { environment }\end{array}$ \\
\hline 52 & 2009 & $\begin{array}{l}\text { Nagar, V., Rajan, M. V., \& Saouma, R. } \\
\text { (2009). The incentive value of } \\
\text { inventory and cross-training in modern } \\
\text { manufacturing. Journal of Accounting } \\
\text { Research }\end{array}$ & \\
\hline 53 & 2009 & $\begin{array}{l}\text { Sarens, G., De Beelde, I., \& Everaert, P. } \\
\text { (2009). Internal audit: A comfort } \\
\text { provider to the audit committee. British } \\
\text { Accounting Review }\end{array}$ & Auditing \\
\hline 54 & 2010 & $\begin{array}{l}\text { Abdel-Maksoud, A., Cerbioni, F., } \\
\text { Ricceri, F., \& Velayutham, S. (2010). } \\
\text { Employee morale, non-financial } \\
\text { performance measures, deployment of } \\
\text { innovative managerial practices and } \\
\text { shop-floor involvement in Italian } \\
\text { manufacturing firms. British } \\
\text { Accounting Review }\end{array}$ & \\
\hline 55 & 2010 & $\begin{array}{l}\text { Kornberger, M., \& Carter, C. (2010). } \\
\text { Manufacturing competition: How } \\
\text { accounting practices shape strategy } \\
\text { making in cities. Accounting, Auditing } \\
\text { and Accountability Journal }\end{array}$ & Strategies \\
\hline 56 & 2011 & $\begin{array}{l}\text { Parker, L. (2011). University } \\
\text { corporatisation: Driving redefinition. } \\
\text { Critical Perspectives on Accounting }\end{array}$ & $\begin{array}{c}\text { Not production } \\
\text { environment }\end{array}$ \\
\hline
\end{tabular}


Table 2 continued

\begin{tabular}{|c|c|c|c|}
\hline & Publication year & MA articles & Excluded due to \\
\hline 57 & 2012 & $\begin{array}{l}\text { Fraser, M. (2012). Fleshing out an } \\
\text { engagement with a social accounting } \\
\text { technology. Accounting, Auditing and } \\
\text { Accountability Journal }\end{array}$ & $\begin{array}{c}\text { Not production } \\
\text { environment }\end{array}$ \\
\hline 58 & 2013 & $\begin{array}{l}\text { Fullerton, R. R., Kennedy, F. A., \& } \\
\text { Widener, S. K. (2013). Management } \\
\text { accounting and control practices in a } \\
\text { lean manufacturing environment. } \\
\text { Accounting, Organizations and Society }\end{array}$ & \\
\hline 59 & 2014 & $\begin{array}{l}\text { Deville, A., Ferrier, G. D., \& Leleu, H. } \\
\text { (2014). Measuring the performance of } \\
\text { hierarchical organizations: An } \\
\text { application to bank efficiency at the } \\
\text { regional and branch levels. } \\
\text { Management Accounting Research }\end{array}$ & Bank sector \\
\hline
\end{tabular}

about the nature of social science on the scale of subjectivism and objectivism. However, in the sorting based on the assumptions of the nature of society, at times it was difficult to distinguish between regulation and radical change. Most articles (independent of the subjective-objective scale) were based on the sociology of regulation change and only one was classified as based on the sociology of radical change.

The classification of paradigms was guided by the stated purpose together with the way the article was written and the way the study was conducted. The following is an example of why a certain article was classified as functionalist: "We argue that decentralization choices are an important determinant of managers' acceptance of accounting innovations and develop two intervening path models to explain why this is so" (Abernethy and Bouwens 2005, p. 219). The nature of society in the above article was considered regulatory since the rhetoric created consensus and illustrated an actual state, in contrast to radical change that would address research as a way to change existing social, political, and economic structures. Furthermore, the article is classified as within the functionalist paradigm because of its objective and analytical nature, embodied by the quotation's rational explanation of social phenomena. An example of classification of the interpretive paradigm is "...the firm was free to construct its own skewed depiction of reality” (Archel et al. 2009, p. 1299). Note that the researcher made the classifications into paradigm and sometimes into theories based on the content in the articles since these aspects were sometimes not accounted for in the articles. For example, at times the articles build on theory without being explicit regarding its label. The research was hence classified into "general sociological concerns" or philosophy of science (Burrell and Morgan 1979, p. 26) of positivism or hermeneutics, and the theories (e.g., contingency theory, principal-agent theory) identified in the literature were classified within the sociological concerns classification.

The purpose of each article was classified as the authors expressed it, but the approach of the study was used when no explicit purpose was expressed (i.e., exploratory, descriptive, or explanatory; Hart 1998, pp. 44-47). Each purpose would 
entail differences in the research design. Exploratory purposes intend to provide better understanding or illuminating a process or a problem. Questions often focus on how, what, when and where. Descriptive purposes intend to understand social phenomenon resting upon empirical observations. Explanatory purposes aim to explain causes of phenomenon, show causality and to suggests reasons for occurrences. However, explanatory research does not necessarily imply producing generalizations, but rather explain the specifics (Scapens 1994).

\subsubsection{Theory classifications}

The articles were classified into theories based on their articulated scientific theory. Theories aim to provide sets of principles that can aid understanding or explanation for a phenomenon or events. At times, no explicit theory was articulated. Rather, the study relied on assumptions from previous research in building their theoretical model.

The problematization of management accounting in production environments was also noted and classified as a "point of departure" (from the researchers' introduction to the study) and/or "conclusion" (from the research findings as a way to give body to management accounting in production environments). This distinction was inductively derived due to a noted pattern in the OM literature as problematizing management accounting in production environments and then leaving it at that, with a solution and/or conclusion detached from the initial problem (i.e., management accounting).

\subsubsection{Method classifications}

In addition, classification was based on the methodology stated in the reviewed articles, such as method (e.g., interview, model, survey) and level of analysis (e.g., empirical such as individual or process or conceptual such as modeling). Last, each article's findings, conclusion, and research agenda were summarized in a classification sheet (see Table 3 for categories). The classifications of context and overall findings were used to give depth to the interpretations of the three main dimensions of paradigm, theory, and methodical issues.

Table 3 shows the categories used for the initial classifications of articles. The descriptive classifications were mainly used for identification of articles. The context and overall findings classifications were essential for classifying the researchers' perceptions of management accounting in production environments.

\subsubsection{Contextual classifications}

The following classifications were made to give context to the studies in the literature, including industry based on the companies' interaction of product and process structure as in the model "process and product life cycle" (Hayes and Wheelwright 1979, p. 135). At times, this separation was not clear but, based on the product structure described in the article, the researcher derived the suggested process structure according to Hayes and Wheelwright's (1979) model. Furthermore, the production environment was classified according to whether the business environment studied was certain or uncertain. 
Table 3 Basic characteristics of the articles

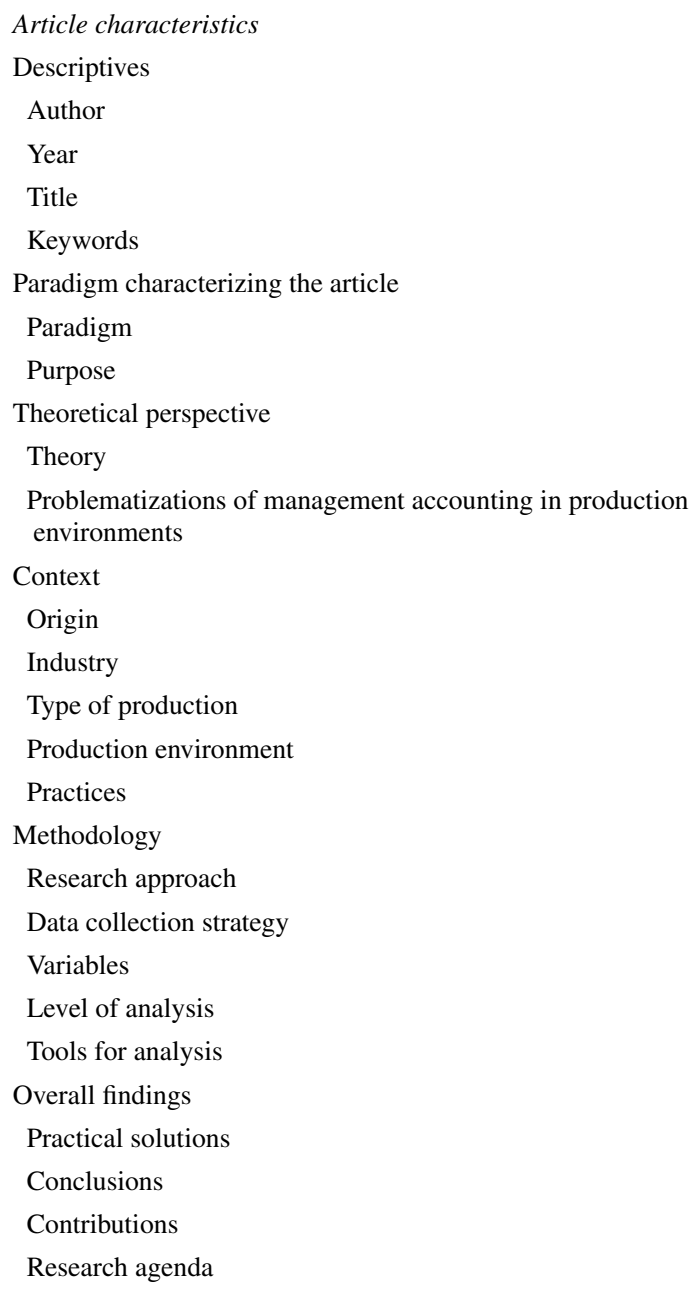

Manufacturing practices and/or accounting practices were classified as described in the articles (e.g., just-in-time (JIT), total quality management, lean production). The origin of the study was classified based on articles reporting empirical research.

\subsection{Processing articles}

In addition to the classification scheme, which reduced the literature to manageable amounts, mind maps were employed to process and analyze the articles. The first mind map was used to find patterns (Feak and Swales 2009, p. 17) within and between the fields since similarities and differences were used primarily in the interface of MA and OM (see Fig. 1). Thereafter, the tentative patterns extracted from the first 


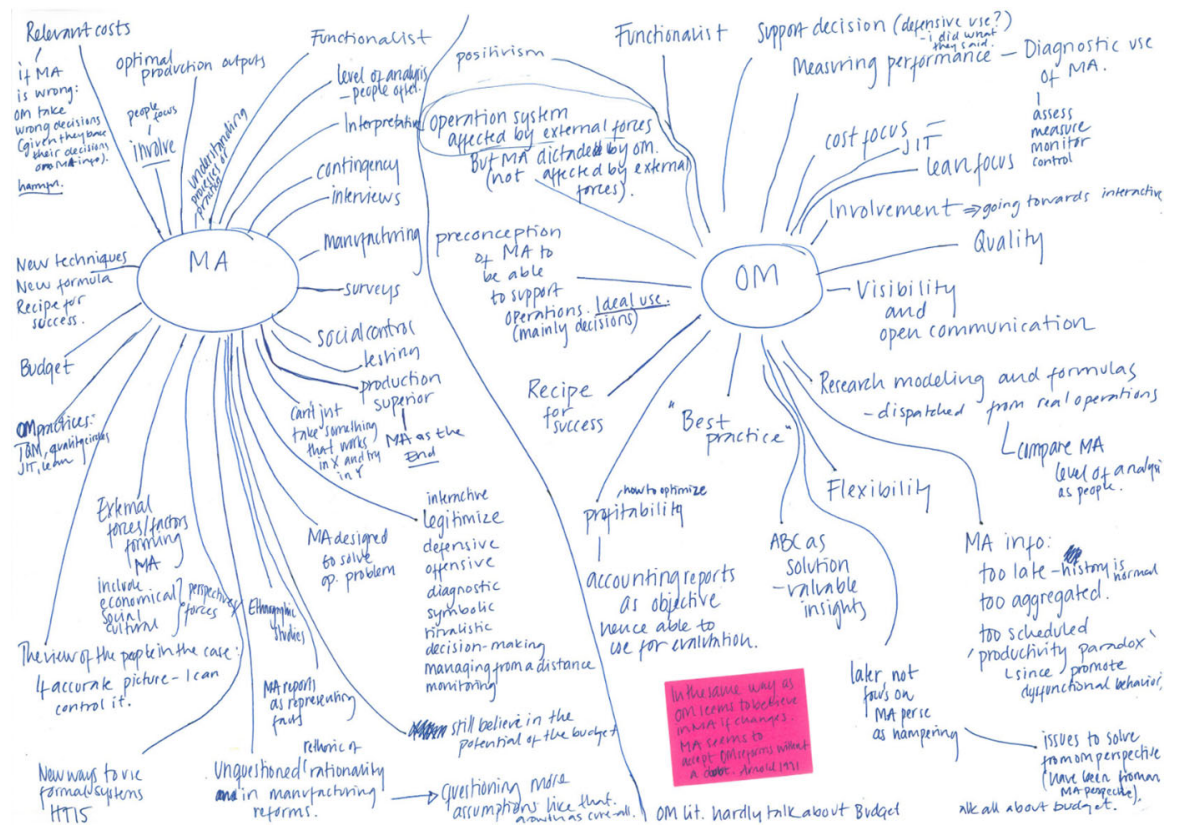

Fig. 1 Mind mapping patterns

mind map were classified on another map in relation to the classification scheme and connected to the articles to provide tentative discussion points. This also provided an opportunity to pause and reflect on the patterns in terms of recurring regularities as well as disconfirming regularities (Miles et al. 1994, p. 246). Hence, the structure of the result is based on the patterns of the mind map and the classification sheet with the aim of providing the reader with a "logical and conceptual reasoning" (Fisch and Block 2018, p. 105).

Figure 1 shows the process of structuring the classifications of articles and verifying or rejecting the emerging patterns. This mind map was created after the classification scheme.

The process of analyzing the results were ongoing, and the classification scheme set the foundation together with the mind map. The tables ${ }^{2}$ illustrating the main results were used to find emerging patterns. Table $4 \mathrm{a}-\mathrm{c}$ exemplify how the underlying research assumptions were derived from the interface between the MA and OM literature. These tables assisted the analysis of management accounting in production environments as expressed in the literature.

Table 4a shows how paradigms was coded and broken down into three emerging patterns of ontological standpoints, stated research questions, and terminology. The first-level coding was based on the results found in Tables 5, 6. The second-level coding was based on the pattern found within each literature classification. The third-level coding was based on the patterns of the literature taken together. Table $4 \mathrm{~b}$ shows how

\footnotetext{
2 Here I refer to the Tables 5, 6, 7, 8, 9 and 10 presenting the main results. These are found in the results section.
} 


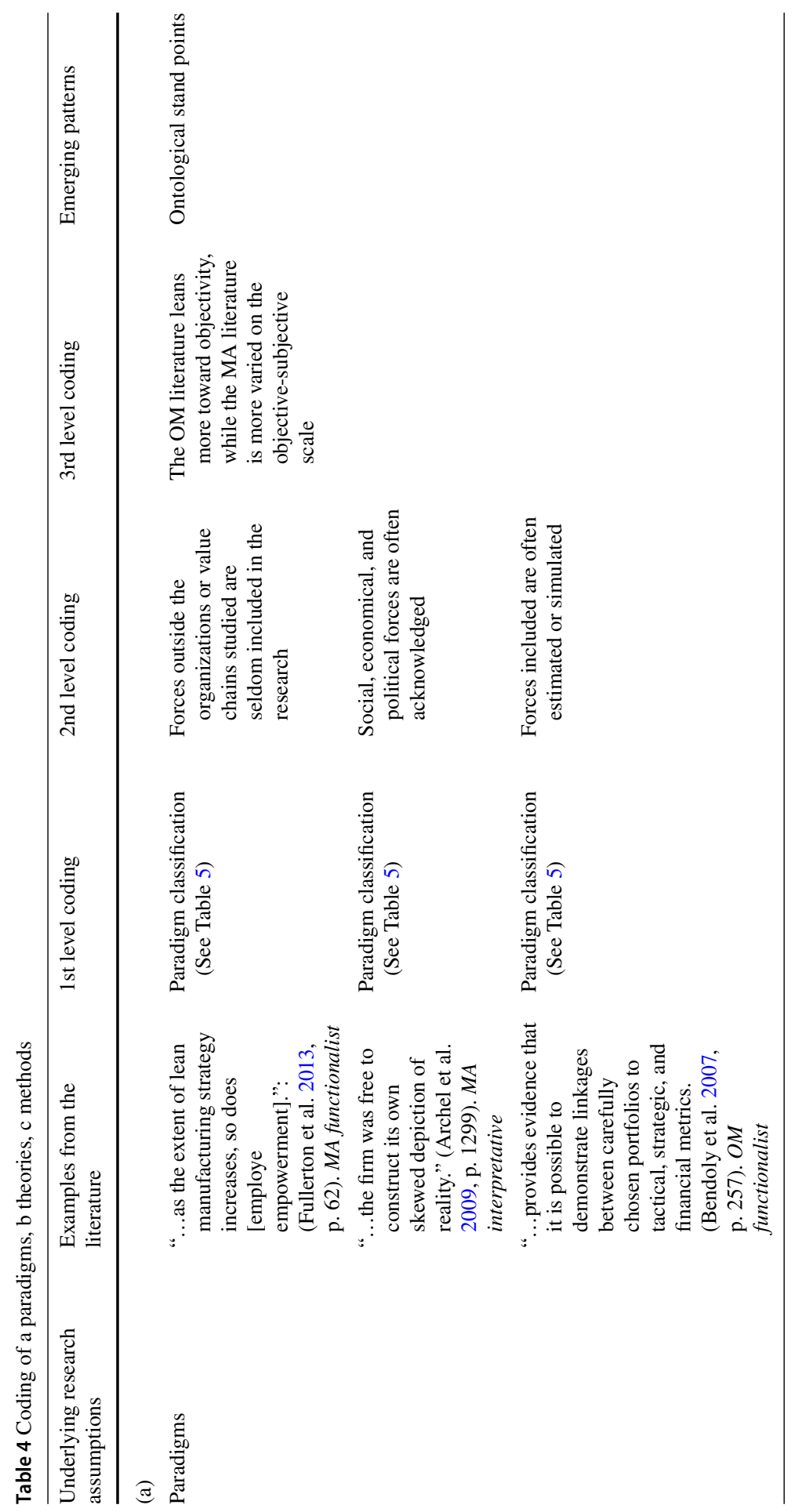




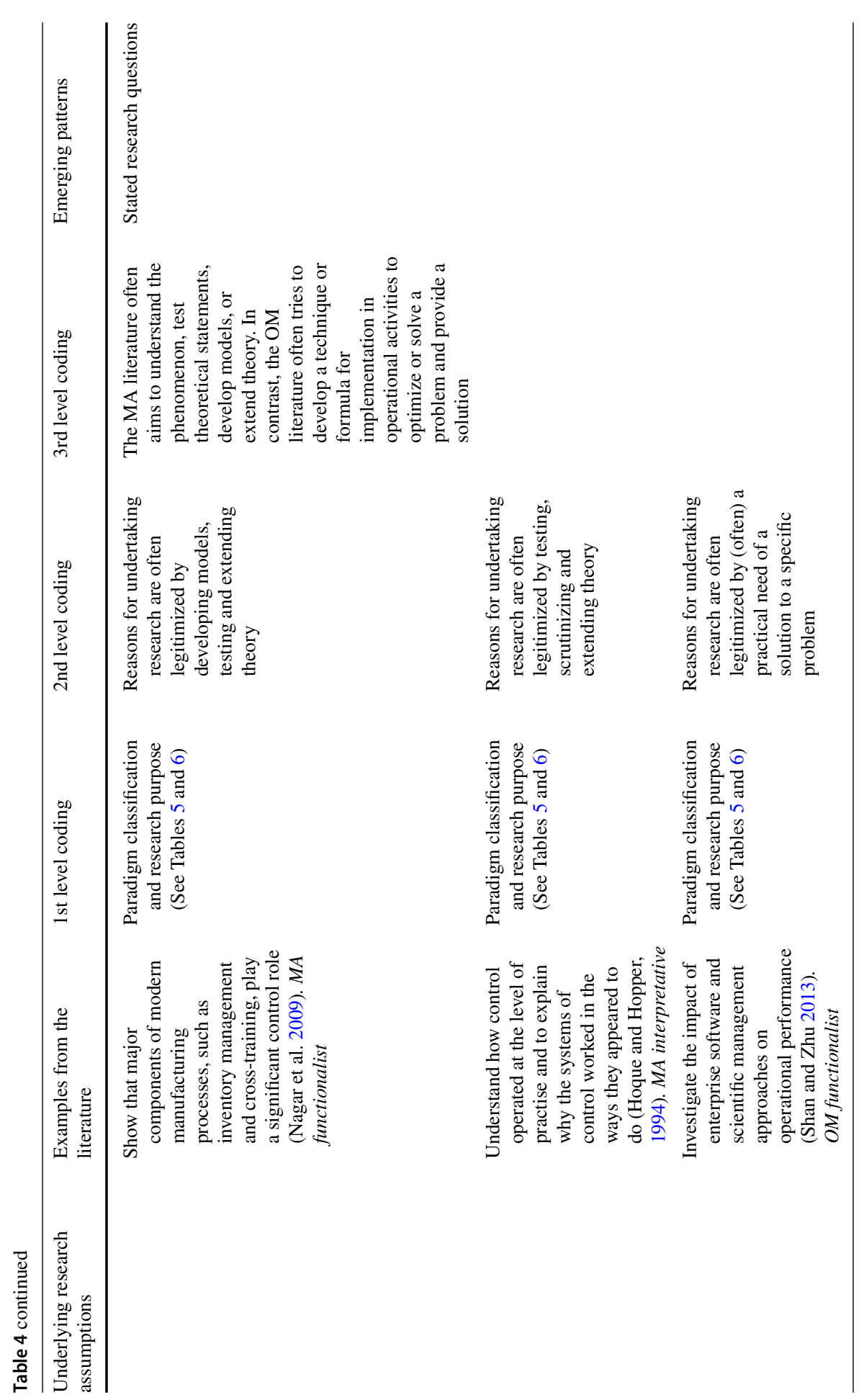




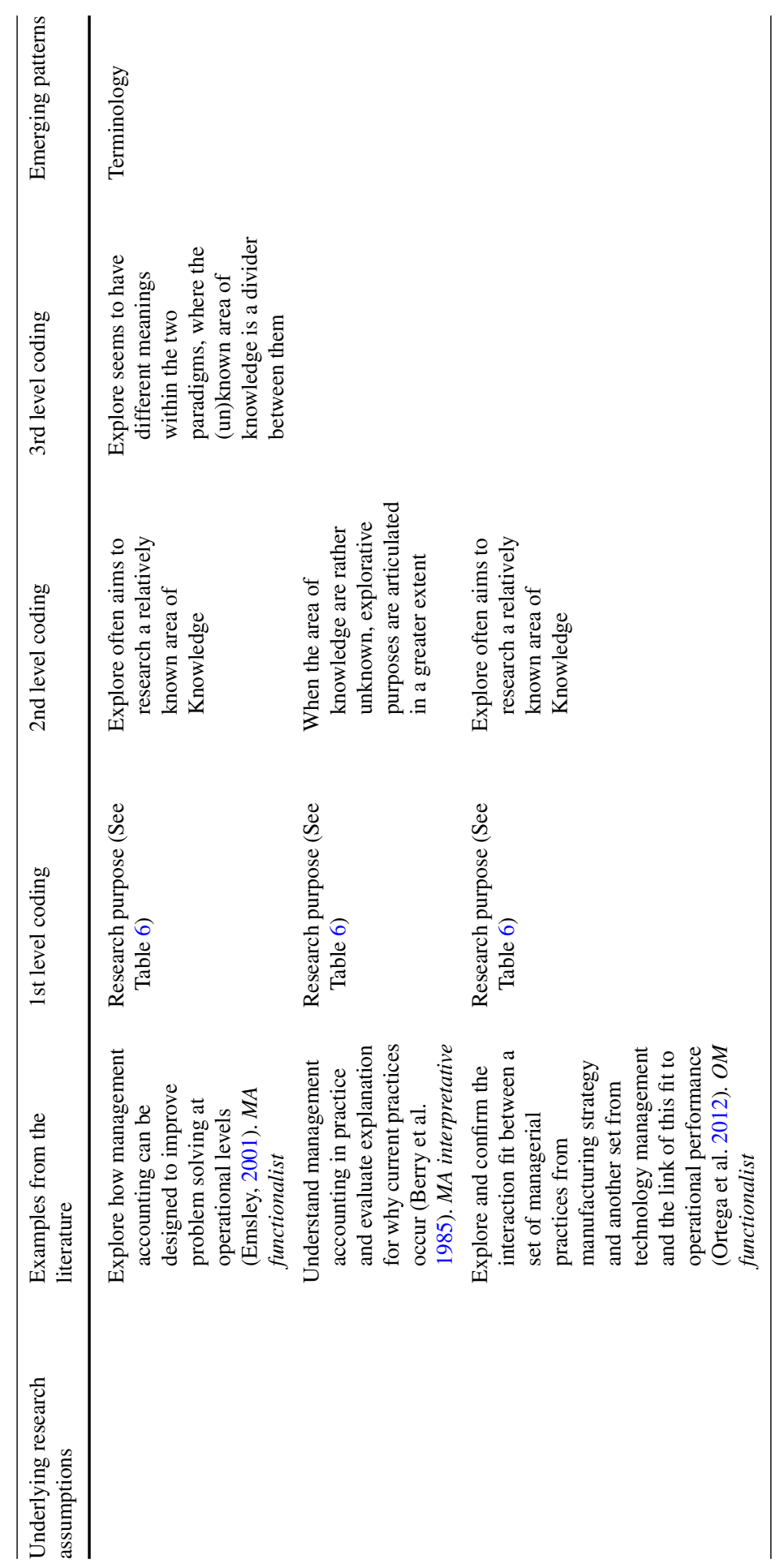




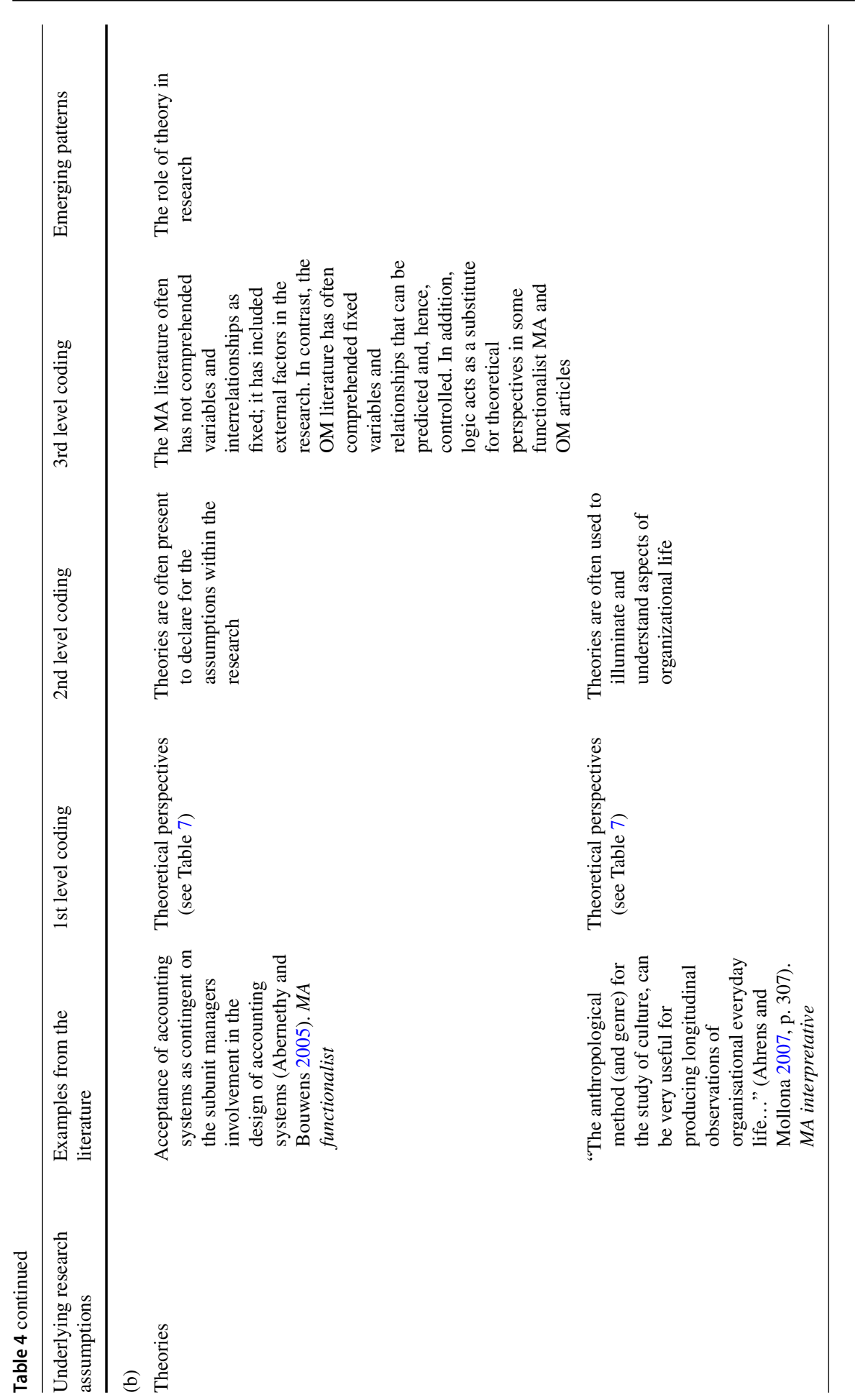



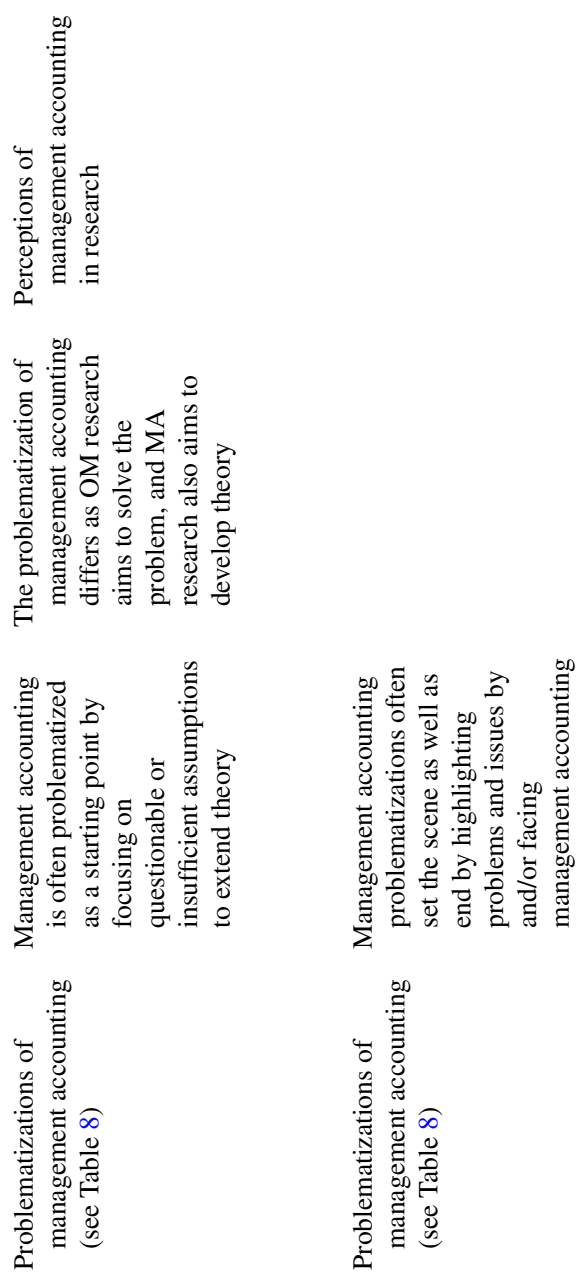

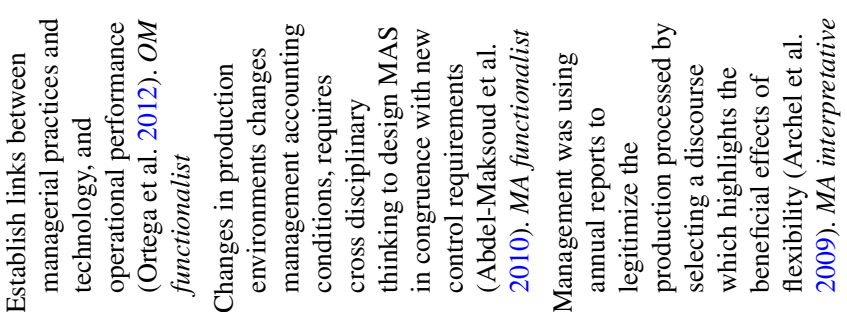

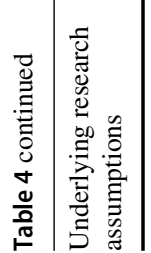




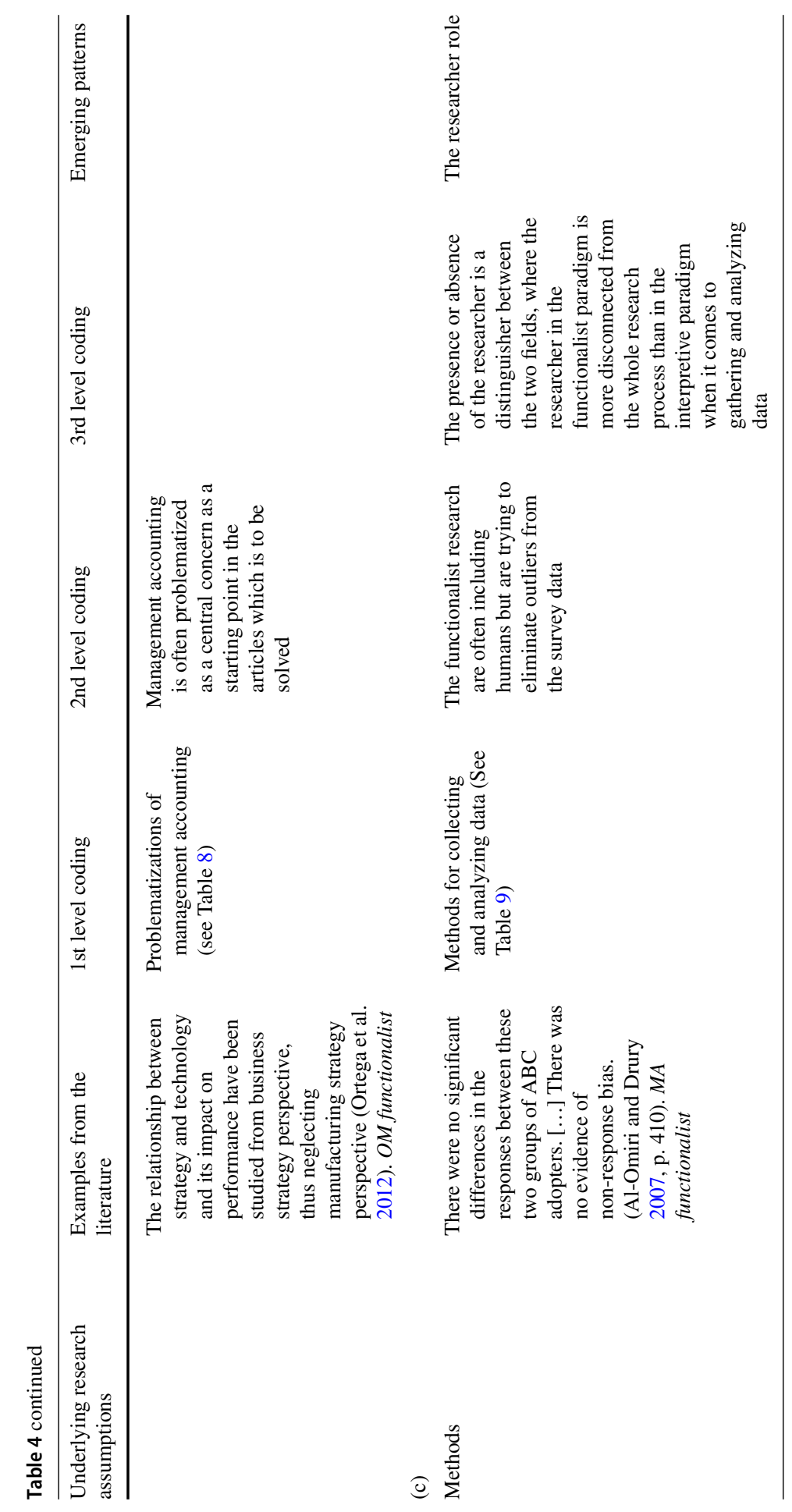




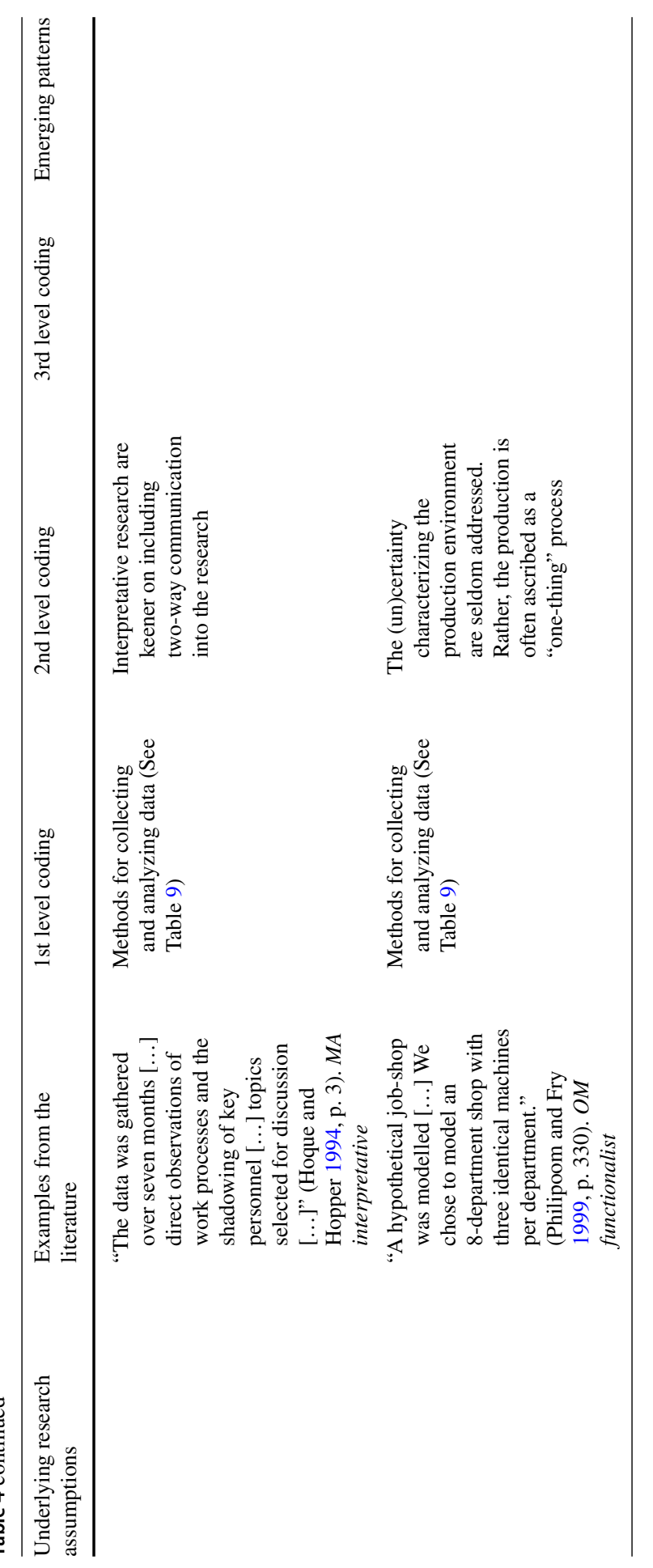




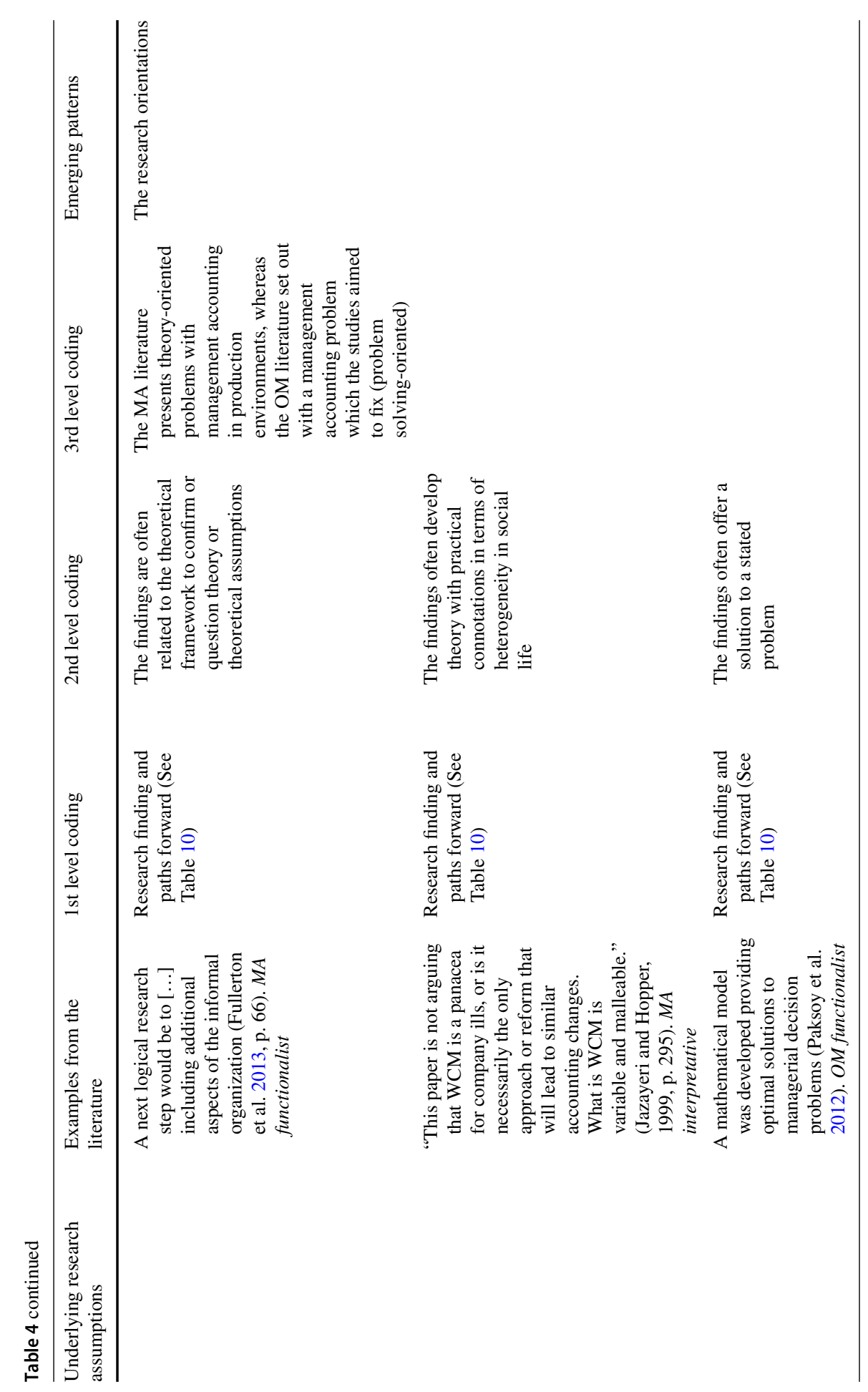


theories was coded and broken down into emerging patterns of the role of theory in research and the views of management accounting in research. Table $4 \mathrm{c}$ shows how methods was coded and broken down into emerging patterns of researcher role and research orientation.

Note that MA researchers were at times authors of articles published in the OM literature (e.g., Bhimani 1994). In addition, some articles could not be classified into a category; hence, they were marked as "unknown" or "N/A."

\section{Results of literature on management accounting in production environments}

The presentation of the literature is based on the schema presented in Table 3 as the underlying assumptions upon which the research rests upon can be found in the choices of paradigm, theory and method made by the researcher. Under each category, the results from the MA literature are presented first (and the results are divided into paradigms, where necessary). Thereafter, the results from the OM literature are presented, followed by a comparison of similarities and differences in the two fields.

The following sections present the paradigms, theories and methods identified within the literature. Each section starts by presenting the results found in the MA literature followed by the OM literature.

\subsection{Paradigms in the reviewed literature}

Paradigms the reviewed literature are based upon the paradigm classifications and research purposes as expressed in the MA and OM literature.

\subsubsection{Two main paradigms in the reviewed literature}

Regarding paradigms, all OM literature is classified as functionalist except one article classified as interpretive. In contrast, the MA literature is more diverse, with some articles based on the functionalist and interpretive paradigms and one on the radical humanist paradigm (see Table 5).

Table 5 shows that the OM articles are classified as functionalist in this review and that the MA articles vary between functionalist and interpretative. The classified functionalist MA articles often include measurable aspects of an organization or its value chain. The interpretive MA literature aims to study sensemaking behavior and practices. The interpretive MA literature includes broader aspects than the organization, such as history, social aspects, and politics. The articles classified as interpretive are written to highlight that accounting is not neutral (or objective). For example, Archel et al. (2009, p. 1291) capture how management through social perceptions gains legitimacy for a new production process using annual reports and official and external documents.

In the functionalist articles, the view of social reality is objective. For example, a study by Bendoly et al. (2007, p. 257) “...provides evidence that it is possible to 
Table 5 Classification of articles into paradigms

\begin{tabular}{|c|c|}
\hline Functionalist (17 articles) & Interpretive (1 article) \\
\hline \multicolumn{2}{|l|}{ Operations management } \\
\hline Bakke and Hellberg (1991) & Bhimani A (1994) \\
\hline \multicolumn{2}{|l|}{ Datar et al. (1991) } \\
\hline \multicolumn{2}{|l|}{ Corbey (1994) } \\
\hline \multicolumn{2}{|l|}{ Chang and Lee (1996) } \\
\hline \multicolumn{2}{|l|}{ Ghalayini et al. (1997) } \\
\hline \multicolumn{2}{|l|}{ Tayles and Walley (1997) } \\
\hline \multicolumn{2}{|l|}{ Philipoom and Fry (1999) } \\
\hline \multicolumn{2}{|l|}{ Spedding and Sun (1999) } \\
\hline \multicolumn{2}{|l|}{ Kirche and Srivastava (2005) } \\
\hline \multicolumn{2}{|l|}{ Bendoly et al. (2007) } \\
\hline \multicolumn{2}{|l|}{ Chen (2008) } \\
\hline \multicolumn{2}{|l|}{ Filomena et al. (2011) } \\
\hline \multicolumn{2}{|l|}{ Ortega et al. (2012) } \\
\hline \multicolumn{2}{|l|}{ Paksoy et al. (2012) } \\
\hline \multicolumn{2}{|l|}{ Arya et al. (2014) } \\
\hline \multicolumn{2}{|l|}{ Shan and Zhu (2013) } \\
\hline \multicolumn{2}{|l|}{ Darlington et al. (2015) } \\
\hline Functionalist (11 articles) & Radical Humanist (1 article) \\
\hline \multicolumn{2}{|l|}{ Management accounting } \\
\hline Banker et al. (1988) & Uddin and Hopper (2001) \\
\hline Mia (2000) & Hoque and Hopper (1994) \\
\hline Reid and Smith (2000) & Arnold (1999) \\
\hline Emsley (2001) & Jazayeri and Hopper (1999) \\
\hline Lin and Yu (2002) & Ahrens and Mollona (2007) \\
\hline Abernethy and Bouwens (2005) & Lowe and Koh (2007) \\
\hline Abernethy et al. (2005) & Archel et al. (2009) \\
\hline Al-Omiri and Drury (2007) & \\
\hline Nagar et al. (2009) & \\
\hline Abdel-Maksoud et al. (2010) & \\
\hline Fullerton et al. (2013) & \\
\hline
\end{tabular}

demonstrate linkages between carefully chosen portfolios of tactical, strategic, and financial metrics." The article is functionalistic in terms of the presentation of tangible links between measures that are shown evidentially.

In comparisons of the two fields, the MA literature shows variance regarding classification of paradigm, whereas the OM literature is mainly classified within the functionalist paradigm. In sum, the OM literature leans more toward objectivity, while the MA literature has more variation with respect to the objective-subjective scale. 


\subsubsection{Research purposes in the reviewed literature}

The literature mainly focuses on two types of purposes. The explanatory purpose is most common in both the OM and MA literature, closely followed by exploratory purposes (see Table 6).

Table 6 shows how the MA and OM literature addresses research with varying purposes. The purpose of explaining a phenomenon or predicting an outcome is common in the functionalist MA literature. However, the purpose of explaining is related to existing research within the field. If a specific problem needs to be solved, it would require extensive knowledge of the field and the process, which is often built on the logic of the specific reality. Reid and Smith (2000) test four hypotheses to see what dictates the best choice of management accounting system. Mia (2000) tests a statement of whether information provided by management accounting systems is critical for managers working in a JIT environment. Banker et al. (1988) examine the impact of stochasticity in the production process on relevant costs based on a dynamic assessment of capacity constraints: They develop a model. Furthermore, Fullerton et al. (2013) explain whether and how management accounting practices are used in support of lean manufacturing.

The interpretive MA literature is aimed at understanding phenomena, challenging conventional notions, and/or illustrating a phenomenon with often an exploratory purpose. For example, Berry et al. (1985) try to understand management accounting in practice and evaluate explanations for why current practices occur. Arnold (1999) challenges why manufacturing reforms are accepted in practice unconditionally from a labor perspective. Furthermore, using the actor network theory, Lowe and Koh (2007) present a case to illustrate how accounting inscriptions play a part in the competition for management attention.

The aim in the OM literature is mainly exploratory or explanatory. For example, Ortega et al. (2012) explore and confirm the interaction fit between a set of managerial practices from manufacturing strategy and another set from technology management, as well as the link of this fit to operational performance. Further examples include Corbey (1994), who explores whether relevant cost information is provided to operations upon which operations can base operational decisions. In addition, the purpose expressed in the OM literature includes problem-solving (Chen 2008).

To compare, the stated purpose in the functionalist MA literature tends to be explanatory, whereas the purpose within the interpretive MA literature tends to be exploratory or descriptive. The descriptive purpose aiming to understand a phenomenon does not appear in the OM literature. Rather, the OM literature aims to predict, explain, and at times provide an optimal solution. However, the purposes

Table 6 Research purposes in reviewed literature

\begin{tabular}{lll}
\hline Research purpose & OM & MA \\
\hline Exploratory & 6 & 7 \\
Explanatory & 9 & 9 \\
Descriptive & 3 & 3 \\
\hline
\end{tabular}


Table 7 Theories in the reviewed literature

\begin{tabular}{llll}
\hline $\begin{array}{l}\text { Philosophy of science } \\
\text { Positivism }\end{array}$ & $\begin{array}{l}\text { MA } \\
\text { Positivism }\end{array}$ & $\begin{array}{l}\text { MA } \\
\text { Theormeneutics }\end{array}$ \\
\hline $\begin{array}{l}\text { Theory } \\
\text { Logical argumentation field and paradigm } \\
\text { Contingency theory }\end{array}$ & $\begin{array}{l}\text { Principal-agent theory } \\
\text { Contingency theory } \\
\text { Logical argumentation }\end{array}$ & $\begin{array}{l}\text { Institutional theory } \\
\text { Actor network theory } \\
\end{array}$ & $\begin{array}{l}\text { Practice theory } \\
\text { Legitimacy theory } \\
\text { Contingency theory }\end{array}$ \\
\hline
\end{tabular}

expressed in the OM literature are often explicitly labeled as exploratory. In sum, the MA literature often aims to understand a phenomenon, test theoretical statements, develop models, or extend theory. In contrast, the OM literature has often tried to develop a technique or formula for implementation in operational activities to solve a problem and provide a solution.

\subsection{Theories in the reviewed literature}

Theories in the reviewed literature are presented based on the classifications of theories used in the research, modes of presentation in management accounting in production environments, and research problematizations within the articles.

\subsubsection{Theories within the reviewed articles}

The theories differ between and within the research fields. In some articles, the theory is addressed, whereas in others it is left unknown. The theories are classified by philosophy of science (see Table 7). In cases where no theory is addressed, logical assumptions guide the study.

Table 7 shows which theories are identified within each research field and whether such theory classified as positivism and/or hermeneutics. The MA literature shows variance in theory. However, the patterns that emerge point to several articles using contingency theory in a normative sense with a problem-solving approach by providing a best practice in a given situation. These articles are also classified within the functionalist paradigm. Hence, when it comes to the MA literature based on the functionalist paradigm, the literature often has a contingency theory perspective. Examples include contingencies such as management accounting playing a more crucial role in environments where managers are responsible for managing their own operations (Mia 2000) and testing whether the best choice of management accounting system is dictated by different variables (Reid and Smith 2000). Furthermore, in an attempt to convert tacit knowledge into organizational knowledge, Abernethy et al. (2005) have organizational members map the drivers of performance rather than modeling a production process. In their suggestion for further research, they point to this map as the foundation for a performance measurement system to understand what factors are contingent on what other factors. 
Positivism is reflected in the functionalist MA research, which implies that the research should be unbiased and representative. Most functionalist MA research is normative in its logic and causality. For example, Nagar et al. (2009) build their study on the principal agent theory, making assumptions from pre-determined patterns of the principal in creating incentives for information sharing on the shop floor. As a result, in these circumstances, information sharing plays a significant control role. In this approach and their mathematical model, they show that excessive inventory might be an equilibrium outcome. The above is an example of how logic is used in the MA literature.

Hermeneutics is reflected in the interpretive MA research, where the aim is to understand management accounting from social actors' point of view. However, the distinction between hermeneutics and logic is not always clear. If a researcher interprets a phenomenon, the research can use logic (hypothetic-deductive method) (Føllesdal 1979) to make sense of the interpretation. Practice theory can be considered related to hermeneutics because it follows the actors in their daily activities. The review shows different ways to interpret a phenomenon, such as using actor network theory and how accounting "facts" can be considered truth and "black boxed" (Lowe and Koh 2007). Other ways of interpreting a phenomenon and bringing new knowledge include seeing the world as socially constructed (Arnold 1999) and using legitimacy theory. The latter is used to increase understanding of the motives that lead managers to engage in social and environmental disclosure activities (Archel et al. 2009).

The OM literature often builds on instrumentality and logic. The arguments are often normative and there seems to be a preconception (c.f. Bhimani 1994) of what management accounting should provide. For example, some researchers have considered management accounting as providing relevant information (Corbey 1994), objective accounting information (Chang and Lee 1996), and reliable measurements. Furthermore, a single view of potential best accounting practice (Tayles and Walley 1997) needs to be found or developed. The results indicate that the OM literature is characterized by positivism and some studies use deterministic models (Shan and Zhu 2013) or deterministic assumptions of, for instance, orders being either fully accepted or fully rejected when building their models (Kirche and Srivastava 2005). In addition, Arya et al. (2014) assume a rational market in their article, which illustrates the functionalism identified in the reviewed literature. The OM literature has focused on contingency theory to some extent. For example, researchers have examined the interaction fit between a set of managerial practices from manufacturing strategy and another set from technology management and the link of this fit to operational performance (Ortega et al. 2012) and investigated when an accounting strategy is appropriate with what manufacturing strategy (Tayles and Walley 1997). Causality is also frequent in the OM literature; an example is exploring how to realize the optimization of strategic and tactical decisions together in the supply chain (Paksoy et al. 2012).

In a comparison of the two fields, the results within the MA literature are broader and vary in theories. Functionalist MA articles are often built with traits of contingency theory, whereas interpretive articles are more diversified. The patterns that emerge point to positivism in the OM literature. An example is the OM literature's confidence in objective accounting measures leading to improved performance (c.f. Bendoly et al. 2007). In sum, the MA literature often does not comprehend variables 
and interrelationships as fixed; it includes external factors in the research. In contrast, the OM literature often comprehends fixed variables and relationships that can be predicted and, hence, controlled. The normative aspects distinguish contingency theory between the fields and paradigms. In addition, logic acts as a substitute for theory in some functionalist MA and OM articles.

\subsubsection{Research problematizations of management accounting}

The patterns that emerge point to similar problematizations in the fields. The argument that management accounting is insufficient for operations is common. However, other problematizations are also identified. The problematizations of management accounting in the articles are classified as the "point of departure" of the study and/or as the "conclusion" from the study (see Table 8).

Table 8 shows the problematizations of management accounting in production environments as expressed in the articles. The columns to the right (marked with an X) show whether the problematization is used as a point of departure in the articles or whether it is used to highlight complexities as conclusions; this continuing problematizing of management accounting in production environments is also offered as a conclusion in the article. The column to the left shows the problematizations used in the articles.

When it comes to the problematization of management accounting in production environments, the review of the MA literature reflects variance. In the functionalist MA literature, the problematization often focuses on aspects in earlier research or models that are too simple (Banker et al. 1988), that need to be redesigned (Emsley 2001), or for which something is inaccurate with respect to the assumptions (Abernethy and Bouwens 2005). In interpretive research, the problematization is often comprehensive and includes aspects that do not receive the same attention in functionalist research. A few examples of how management accounting is problematized in interpretive research are that practical observations cause problematizations, such as managers who claim that management accounting is too far from "reality" (Hoque and Hopper 1994), that informational uncertainty reinforces the lack of significance in accounting reports (Berry et al. 1985), and that accountants and operations managers have different goals and do not understand each other (Lowe and Koh 2007). Another way of problematizing involves the researchers themselves questioning management accounting as taken for granted (Ahrens and Mollona 2007) or lean manufacturing as beneficial for all and everything (Archel et al. 2009). Thus, the problematizations are rather theory-oriented, with no clear solutions offered in the conclusions.

The problematization of management accounting in the OM literature is often based on arguments such as management accounting signaling that history is the norm (Spedding and Sun 1999), that is, the status quo. Management accounting is considered incapable of being used for decision-making since it does not include production parameters (Kirche and Srivastava 2005) and sends the wrong signals to managers (Datar et al. 1991). Thus, the wrong signals are also considered harmful since operational members will "cherry pick" to increase their own performance at the expense of firm performance (Philipoom and Fry 1999) or lose competitive advantage due to poor management accounting systems (Tayles and Walley 1997). Furthermore, management accounting is problematized as inflexible (Corbey 1994) and unable to 
Table 8 Problematization of management accounting in production environments in the reviewed literature

OM Author Point of departure Conclusion

Problematization of management accounting in production environments

Too focused on short term

Too simplified

Need flexibility

Feedback loop neglected

Wrong signals to managers

Poor system causes loss in competition

Dysfunctional, ambiguous, or insufficient measures

Too late

Too aggregated

Inaccurate

A preconception that MA has a pre-existing potential for fulfilling its role

Not for factory floor

Insufficient for operational practices

Non-visible information

Manufacturing strategy perspective neglected in the study of strategy and technology relationship
Bakke and Hellberg (1991) X

Kirche and Srivastava (2005) X

Corbey (1994), Chen (2008) X

Ghalayini et al. (1997), Chen X;X (2008)

Datar et al. (1991) X

Tayles and Walley (1997) X

Chang and Lee (1996), $\quad$ X;X;X;X

Philipoom and Fry (1999),

Kirche and Srivastava

(2005), Chen (2008)

Bakke and Hellberg (1991), X;X

Spedding and Sun (1999)

Spedding and Sun (1999) X

Datar et al. (1991), Bakke and $\quad \mathrm{X} ; \mathrm{X} ; \mathrm{X}$

Hellberg (1991), Spedding and Sun (1999)

Bhimani (1994)

X

X

Ghalayini et al. (1997) X

Bakke and Hellberg (1991), X;X;X Bendoly et al. (2007), Chen (2008)

Corbey (1994)

X

Ortega et al. (2012) X

Author Point of departure Conclusion

Target and measure not aligned

Tension between managerial levels

Emsley (2001)

$\mathrm{X}$

Abernethy and Bouwens

$\mathrm{X}$ (2005)

Top-down models

Abernethy et al. (2005)

X

Produce "accounting facts"

Lowe and Koh (2007)

$\mathrm{X}$

Berry et al. (1985)

$\mathrm{X}$

Hoque and Hopper (1994)

$\mathrm{X}$

Too far from reality due to strict central control

Useless or not worth the effort to use 
Table 8 continued

\begin{tabular}{|c|c|c|c|}
\hline MA & Author & Point of departure & Conclusion \\
\hline $\begin{array}{l}\text { Accounting becomes taken for } \\
\text { granted }\end{array}$ & Ahrens and Mollona (2007) & $\mathrm{X}$ & \\
\hline Lean beneficial for all & Archel et al. (2009) & $\mathrm{X}$ & \\
\hline MA needs to adapt to changes in $\mathrm{OM}$ & $\begin{array}{l}\text { Abdel-Maksoud et al. (2010), } \\
\text { Fullerton et al. (2013) }\end{array}$ & $\mathrm{X} ; \mathrm{X}$ & \\
\hline Unknown links between factors & Al-Omiri and Drury (2007) & $\mathrm{X}$ & \\
\hline $\begin{array}{l}\text { Too simple calculations and neglect } \\
\text { of important variables }\end{array}$ & Banker et al. (1988) & $\mathrm{X}$ & \\
\hline $\begin{array}{l}\text { Decoupled management accounting } \\
\text { system }\end{array}$ & Berry et al. (1985) & & $X$ \\
\hline Slack built into budgets & Hoque and Hopper (1994) & & $\mathrm{X}$ \\
\hline $\begin{array}{l}\text { Include more aspects when analyzing } \\
\text { production process }\end{array}$ & Nagar et al. (2009) & $\mathrm{X}$ & \\
\hline $\begin{array}{l}\text { OM and MA as two competing } \\
\text { groups }\end{array}$ & Lowe and Koh (2007) & & $\mathrm{X}$ \\
\hline $\begin{array}{l}\text { Inadequate and uncritical } \\
\text { assumptions in MA field }\end{array}$ & $\begin{array}{l}\text { Berry et al. (1985), Arnold } \\
\text { (1999), Hoque and Hopper } \\
\text { (1994), Jazayeri and } \\
\text { Hopper (1999), Uddin and } \\
\text { Hopper (2001) }\end{array}$ & & $\mathrm{X} ; \mathrm{X} ; \mathrm{X} ; \mathrm{X} ; \mathrm{X}$ \\
\hline
\end{tabular}

support improvements as it fails to provide feedback (Ghalayini et al. 1997). Corbey (1994) concludes that the increased discontent with management accounting is due to its inability to provide relevant cost information to operations.

In the OM literature, problematizations separated by almost 20 years are at times similar. For example, Chen (2008) stresses that the proposed integrated performance measurement systems have failed since they neglect feedback loops, are not dynamic, and cannot respond to the changing manufacturing environment. This can be compared to the problematization by Datar et al. (1991), who stress that management accounting fails to trace cost savings to new manufacturing practices, provides inaccurate cost information, sends incorrect signals to managers, and therefore preserves inefficient operations management practices. Part of the difference is that the operations management reform in the early research is not implemented because of management accounting failures in identifying action to comply with the reform. However, in the more contemporary research, reform has occurred, but management accounting has failed to assist operations during the reform.

To compare, the functionalist MA research often problematizes management accounting in production environments by focusing on problems to be solved and extending theory or closing existing theory gaps and by assuming that management accounting is not sufficient for operational activities. The interpretive MA research varies to include aspects of management accounting as insufficient for operational activities, but also to include concerns about showing aspects that have occurred in operations. In the OM literature, the problematization of management accounting is 
presented as failing in many aspects when it comes to production environments, and often a specific problem with potential to be solved is targeted. In sum, the MA literature presents theory-oriented problems with management accounting in production environments, whereas the OM literature sets out with a management accounting problem that the studies aimed to fix. In other words, the OM literature is rather problem solving-oriented. In addition, some problematizations are similar to problematizations of 20 years ago.

\subsection{Methods in the reviewed literature}

Methods in the reviewed literature are presented by the data collection strategies and analytical tools, and findings and research agendas.

\subsubsection{Data collection strategies and analytical tools}

Regardless of field or classified paradigm, research methods vary (see Table 9). Empirical studies are conducted in both MA and OM using surveys, interviews, and archival material, and in both fields, laboratory research is conducted using formulas and calculations.

Table 9 shows the occurrence of each method in the research fields of MA and OM, respectively. The methods for gathering empirical data in the functionalist MA literature are diverse; they include surveys (Abdel-Maksoud et al. 2010; Abernethy and Bouwens 2005; Al-Omiri and Drury 2007; Fullerton et al. 2013), interviews (Reid and Smith 2000; Mia 2000; Lin and Yu 2002; Emsley 2001), meeting attendance (Emsley 2001), and mathematical calculations (Nagar et al. 2009). However, analysis of the empirical data is often separated from the collection process, using formulas, statistics, and regressions, building models, and testing variables.

The methods for gathering empirical data in interpretive MA research include interviews, observations, document reviews, and shadowing. Using these approaches, researchers aim to understand a phenomenon or incorporate dimensions by using their

Table 9 Methods for collecting and analyzing data in the reviewed literature

\begin{tabular}{lll}
\hline Identified research methods & Occurrence in OM & Occurrence in MA \\
\hline Statistics & Yes & Yes \\
Formulas and/or calculations & Yes & Yes \\
Interviews & Yes & Yes \\
Meeting attendance & - & Yes \\
Model development & Yes & Yes \\
Observations & - & Yes \\
Shadowing & - & Yes \\
Archival review & Yes & Yes \\
Survey & Yes & Yes \\
Simulation & Yes & - \\
\hline
\end{tabular}


own senses guided by theories. Included are contextual factors such as industry, type of production, and production environment. However, all aspects depend on the research purpose and research questions. For example, using participant observation, Ahrens and Mollona (2007) find subcultures within a steel mill, where some groups use informal management accounting information in their practices shaped by their "notions of economic success" (Ahrens and Mollona 2007, p. 329). The interpretation is the focus and the researcher's role is a natural part of the study.

The OM literature is based on quantitative methods. Building models and conducting simulations are methods frequently used in OM research, where the model is later tested in a case. For example, Shan and Zhu (2013) use empirical material of 1286 financial reports to test the impact of enterprise systems on operational performance (inventory). However, since the forecasts are unknown, they must simulate them. Using simulations, Philipoom and Fry (1999) aim to test whether an operations management practice can compensate for dysfunctional behavior from management accounting measures. Kirche and Srivastava (2005) provide an integrated operational cost model that explicitly links customer orders, cost of resource consumption, and capacity usage to optimize profitability. Chen (2008) presents a case simulation to verify the practical suitability of his proposed system. Furthermore, questionnaire surveys to test hypotheses are also found in the operations management literature (Chang and Lee 1996; Ortega et al. 2012). The focus is on testing and providing evidence of the existing theory. However, other methods are also employed, including documents to use cash flow analysis (Corbey 1994) to explore whether relevant cost information is provided to operations for decision-making.

The methods described in the literature are to a large extent similar, but they are used with different intentions. Functionalist MA research often uses large amounts of quantitative empirical data but also uses single problem-solving situations (c.f. Kihn and Näsi 2010). The interpretive MA research often uses case studies, histories, and dialogues. Regardless of empirical case study or laboratory research, most research from both fields has examined industry (e.g., manufacturing as prominent, and less on extractive) and type of production (e.g., assembly line). However, the (un)certainty characterizing the production environment has seldom been addressed. Rather, it is often called a "one-thing" process.

In sum, the presence or absence of the researcher is a distinguisher between the two fields, where the researcher in the functionalist paradigm is more disconnected from the research process than in the interpretive paradigm when it comes to gathering and analyzing data. There is no need to follow the process if the aim is not to understand the phenomenon. Rather, distance might be desirable if the researcher does not wish to affect the phenomenon.

\subsubsection{Management accounting findings and paths forward in reviewed literature}

Management accounting's potential achievements in production environments differs between the fields. The findings from the MA literature are often characterized by causality or address alternative dimensions of management accounting but not always with a clear goal. The findings from the OM literature are characterized by causality and a problem-solving orientation (see Table 10). 
Table 10 Research findings and research agendas provided in the reviewed literature

\begin{tabular}{ll}
\hline OM & MA \\
\hline $\begin{array}{l}\text { Research findings and research agendas provided in the reviewed literature } \\
\text { Causality }\end{array}$ & $\begin{array}{l}\text { Causality } \\
\text { Providing theoretical causality to be applied in } \\
\text { practice }\end{array}$ \\
Practical demonstrations & \\
$\begin{array}{l}\text { Solution-oriented } \\
\text { Providing script for success } \\
\text { Providing best practices } \\
\text { Interaction promoted }\end{array}$ & $\begin{array}{l}\text { Determined in findings } \\
\text { Provides aspects crucial to consider } \\
\text { Interaction promoted }\end{array}$ \\
& $\begin{array}{l}\text { Alternative roles } \\
\text { Weaknesses with the conventional role }\end{array}$ \\
& $\begin{array}{l}\text { Identifying practical problems } \\
\text { Identifying informal roles }\end{array}$
\end{tabular}

Table 10 illustrates how the OM literature is identified as more oriented toward problem-solving whereas the MA literature is identified to be oriented more toward theory and practice.

The findings in the functionalist MA literature address aspects crucial for practitioners and/or researchers to consider. For example, Mia (2000) finds that in environments where managers are responsible for managing their own operations, management accounting system information plays a more crucial role and that JIT adopters with high provision of information from management accounting systems earn high profit. This strand of research has pointed out certain requisites that (when fulfilled) produce a specific outcome. Fullerton et al. (2013) report that lean manufacturing is positively related to the use of a simplified strategic reporting system. Causality prevails in the functionalist MA literature. However, the functionalist MA literature also highlights additional aspects that may be important to consider. For example, Emsley (2001) notes that a debate regarding the usefulness of formal systems of variance analysis arises when the interactive use of management accounting is introduced.

The interpretive MA literature highlights issues with management accounting that are often observed or identified in practice but do not receive much attention in research based on the conventional view of management accounting. The informality, practical problems, and weaknesses with the prevailing paradigm and management accounting being used for more than fulfilling objectives are examples of such issues. As an example of findings based on interpretive research, Berry et al. (1985) report that managers build their own information systems due to ambiguous formal accounting reports. The informal management accounting systems are difficult to capture, but the interpretive MA research has reported that where management accounting fails in supporting and controlling operations, social control becomes dominate (Arnold 1999; Hoque and Hopper 1994). Furthermore, Berry et al. (1985) find that managers see management accounting as an end, not a means for reaching an end. 
Hoque and Hopper (1994) identify formal control as a means of gaining external legitimacy. Hence, the interpretive MA literature is more critical in its findings, challenging the status quo, and addresses alternative dimensions of management accounting.

The findings in the OM literature are often phrased in terms of solutions to problems or evidence of a predicted outcome. Hence, the OM literature frequently provides scripts for success and solutions. For example, Bakke and Hellberg (1991) find (despite critical aspects of each of the techniques) that activity-based costing (ABC) and optimized production technology (OPT) complement each other. In lean environments, the two practices are considered to have the potential to support production (in producing maximum). Datar et al. (1991) use ABC to highlight real costs and Spedding and Sun (1999) argue that ABC has the potential to be a reliable decision-making support mechanism. The solutions are often built on best practices and consistency. For example, the best practice manufacturing strategy should be aligned with the best accounting practice, and consistency is needed between functional (operations management) strategies and management accounting for company survival (Tayles and Walley 1997). However, Bhimani (1994, p. 30) argues that "[t]he search for a 'better' accounting assumes that accounting has a pre-existing potential for fulfilling its intended roles."

Furthermore, the OM literature advocates open communication (Ghalayini et al. 1997) and visibility (Corbey 1994). Arguments stressing the importance of a factor in achieving a desired outcome are common. For example, Chang and Lee (1996) provide evidence of the need to enhance bottom-up management in JIT environments. Spedding and Sun (1999) show that new methods of evaluating ABC can render $\mathrm{ABC}$ a communication tool. Other OM literature has gone in the opposite direction and created a mathematical model to solve decision-making problems (in contrast to personal interplay) in a supply chain (Paksoy et al. 2012). Philipoom and Fry (1999) introduce an operations management practice of order review/release (ORR) as a solution to problems arising from management accounting. Hence, one solution offers interactive forms of operations and accounting.

To compare, the findings in the functionalist MA literature versus the interpretive MA literature are more definite and determined. The interpretive MA research highlights issues with management accounting to a greater extent and extends management accounting. The OM research findings provide solutions to staged practical problems using variables. In sum, the OM literature findings are similar to those of the functionalist MA literature to some extent. However, they differ in terms of orientation. The OM literature is more oriented toward evidentially showing or demonstrating practical solutions, whereas the MA functionalist literature focuses on theory by developing frameworks or filling research gaps. The interpretive MA research often highlights problems with management accounting that need to be addressed in production environments. 


\section{Discussion}

This review provides a basis to discuss the underlying assumptions upon which the research within the MA and OM fields rests. The discussion follows the same structure as the results section but discusses the emerging patterns derived in Table $4 \mathrm{a}-\mathrm{c}$ (see Table 11).

Table 11 shows that the underlying assumptions are derived from the paradigms, theories and the methods.

\subsection{The underlying research assumptions}

\subsubsection{Paradigms}

The review shows that MA and OM differ in terms of paradigm. These paradigmatic differences are manifested via ontological standpoints, stated research questions, and definitions of exploratory research in the two fields of study.

The MA literature is more varied on the objective-subjective scale and paradigms travel across this "divide" (Ahrens 2008), while the OM literature leans more toward objectivity regarding ontological standpoints. This divide is potentially troublesome if it means that the fields fail to acknowledge research from other paradigms or fields, thereby underpinning the prevailing pursuit of management accounting suitable for production environments and leaving assumptions undisturbed, rather than creating dialogue and learning between the fields. Already Burrell and Morgan (1979, p. 23) elevate the importance of research with different standpoints to deliver different concepts and analytical tools. Taken-for-granted theories and methods prevailing in the core research of a field can lead to paradigmatic homogeneity. This is argued having implications for research as paradigmatic homogeneity only would provide marginal research contributions (Lukka 2010). Research credibility may be drained as unique and perhaps important research questions are left unaddressed (Merchant 2010) or fundamental assumptions are left unquestioned (Lukka and Mouritsen 2002). This tendency towards being too narrow and limited may lead to researchers pushing one way of thinking while leaving other questions unanswered (Malmi 2010), with few crossparadigmatic dialogues (Modell 2010). An omission to speak outside one's paradigm may result in introverted dialogues within research fields (Burrell and Morgan 1979, p. 22).

When it comes to its stated research questions, the functionalist MA literature often develops models to explain or understand a reality. In contrast, the interpretative MA literature focuses on showing complexity and problematizing management accounting realities. The OM literature tends to create models and simulations to optimize decision-making, thereby aiming to provide useful tools for practices. These different objectives imply that the fields apprehend different value in different types of research. Acknowledging this could be to look outside the box rather than ignoring differences between the fields. For both research fields there are risks coming from leaving certain questions unanswered based on existing (and accepted) paradigmatic methods (Malmi 2010; Merchant 2010). 


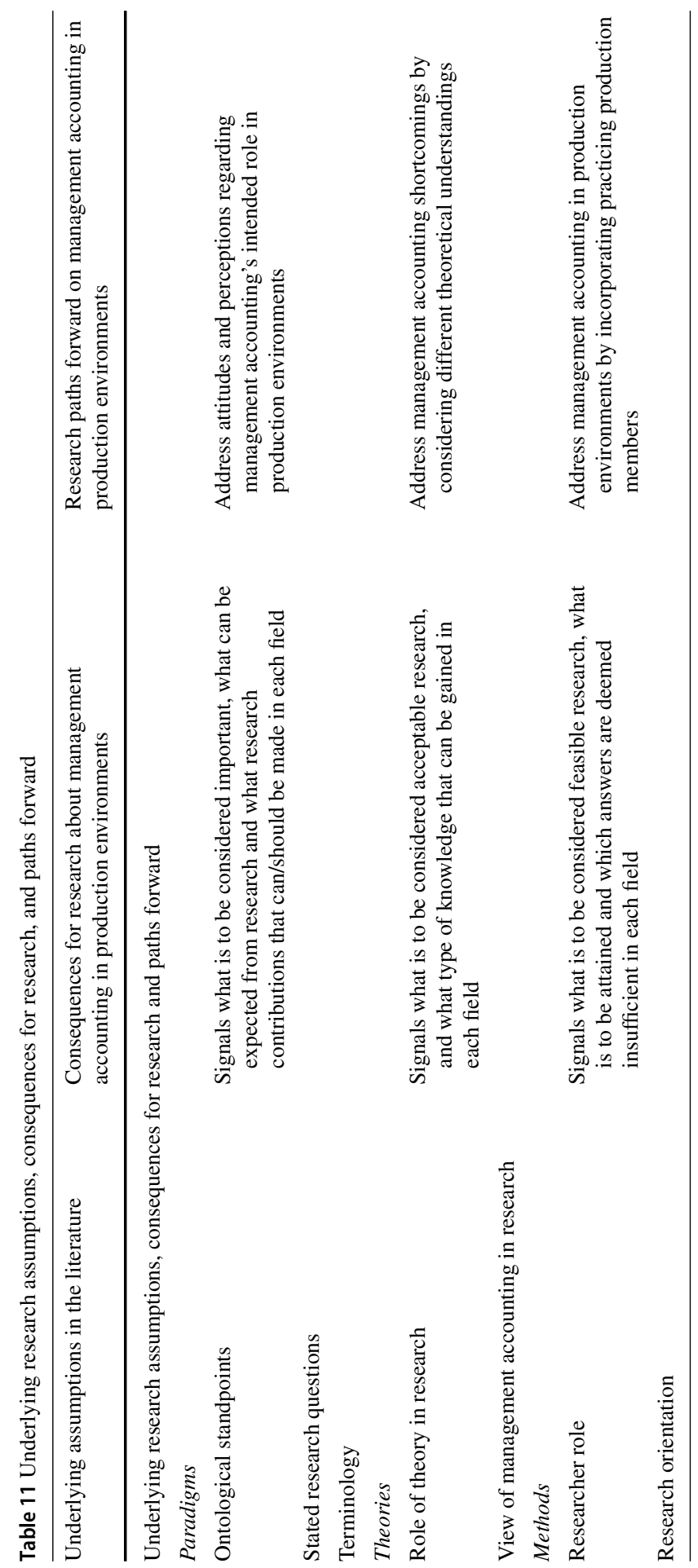


Furthermore, the results point to terminology as a similarity between the fields, but with differences in meaning. OM researchers often use the term "explore" in research. From a MA perspective, however, it is not obvious what "explore" is meant to entail (c.f. Corbey 1994; Ortega et al. 2012). Usually, an exploratory research purpose is considered suitable for unknown and unexplored areas of research (Hart 1998, p. 47). However, if it is possible to build a model, simulate an event, or test a hypothesis, the area must be known. Building on the above reasoning, the fields of MA and OM seem to differ with respect to how to conduct research within each field even when using the same terminology. On the other hand, the OM research tends to show causality but does not necessarily explain the reasons for such cause and effect relationships, thereby rendering an exploratory purpose. Without a theoretical framework it may be hard to explain a causality or phenomenon, but it may be possible to explore them.

The fields' different ontological standpoints, interest in different stated research questions, and different definitions of the same terminology indicates how research are to be conducted and the research considered important within each field. This brings implications in terms of the MA and OM fields' view on research, but also on the expectations of what research can contribute with.

\subsubsection{Theories}

The review shows differences in theories between the fields of MA and OM. The theoretical differences are manifested in the role of theory in research, and views of management accounting in research.

The role of theory in research divides the two fields as the theoretical frame of reference is not always stated explicitly in the literature on management accounting in production environments. While the MA literature provides theories to guide assumptions or understand phenomena in context, the OM literature often does not state an explicit theory; rather, logic acts as a substitute for theory. This implies that the perspective is taken for granted (Latour 1987), would not be important, or does not matter since it will not influence the research (Baldvinsdottir et al. 2010). A lack of theoretical framework is problematic since research resting on different assumptions influences the theoretical perspective (Guba and Lincoln 1994), which if not stated makes the meaning of a concept or perspective unclear. The importance (or lack thereof) of theory is especially central since it can be seen as an extension of the researchers' worldviews. Failure to declare the theories can lead to difficulty in incorporating previous research into new research and in understanding research contributions. The lack of articulated theories in the OM literature may be explained by the orientation towards solutions expressed in the field of OM. The orientation towards theories and theoretical contributions in the field of MA, however, may also cause problems in terms of a lack of practical contributions, thereby fueling the shortcomings of management accounting in production environment.

The instrumental view of management accounting in production environments expressed in OM literature is troublesome as it spirals new techniques in an ongoing search for a "best solution" or "better accounting" (Bhimani 1994, p. 30), where the researchers perhaps seem "oblivious to their own social role in examining the status quo" (Cooper 1980, p. 165). It appears that management accounting is included 
in $\mathrm{OM}$ research due to its potential to support rational decision-making (c.f. Macintosh and Daft 1987, p. 155). In this sense, the OM literature presents management accounting as a provider of objectivity, as instrumentally perceived, and with potential to provide rational choices. An instrumental view of management accounting in production environments complicates what management accounting can obtain in production environments, which is particularly troublesome since it pursues launching new techniques to respond to operational needs. The techniques (and new concepts) introduced to accommodate the shortcomings of management accounting in production environments might therefore be insufficient. Thus, an issue emerges of whether new techniques take the research front very far since similar problematizations are stated in articles more than 20 years after Johnson and Kaplan (1987) started the debate of lost relevance in management accounting.

The fields' differences in role of theory for research and view of management accounting in production environments indicates what is to be acceptable research and what type of knowledge that can be gained. This complicates enhancement of management accounting in production environments. While the field of OM problematizes management accounting in production environments where the solution is one of an operations management, the field of MA contributes to the problem. The functionalist MA research shoulders the responsibility for adapting management accounting techniques to operational needs, whereas the interpretative MA research highlights management accounting's implications in social and political practices, with little practical guidance.

\subsubsection{Methods}

The review shows differences in methods between the MA and OM fields. The methodical differences are manifested in the researcher role and the research orientation.

The functionalist MA literature presents a somewhat detached researcher role, which should not obstruct or intervene in "reality". In the interpretive MA research, interpretation is an ongoing process, and the focus is on the actor(s) and/or actions, with the researcher present during the whole process. This indicates that the researchers' role is central for conducting the research and highlighting the phenomenon within its context (e.g. Chapman 1998). Also the OM literature presents a detached and objective researcher role. This indicates that the researcher can build a model, have someone else test it, and then analyze the results (c.f. Baldvinsdottir et al. 2010). Apparently, the focus is on the results, and the collection of data can be separated from the analysis. In those terms, properly conducted science seems to require appropriate conditions stipulated by the researcher.

The functionalist MA literature has a research orientation towards theory as theoretical developments are highly emphasized. The interpretative MA literature is theory oriented, often trying to understand practice in its social, political and economic environment. The OM literature has an orientation towards problem-solving. Despite instrumental solutions at times presented in the functionalist MA literature, the orientation is towards developing or extending theory. The OM literature pays attention to instrumental solutions and new techniques to solve the problems identified for (often) operational decision-making. Despite its' problem-solving research orientation, prac- 
tices are neglected in the sense of researching informal ways to conduct work. In this way, uniqueness may be disregarded as uninteresting noise (Lukka 2010), as attempts are made to streamline operations. The essence of this difference in orientation is rather contradictory; despite a problem-solving orientation, the concept rather than the practice is central. For instance, operational interactions receive attention in the OM literature, but the operational work members (e.g., operations managers) seldom receive attention in terms of being central and researched. On the other hand, MA research often conducts research with practical emphasis but seems to fail to deliver hands-on practical relevance.

The fields' differences in researcher role and research orientation indicates what is to be considered feasible research. Some questions are left unattended with determined assumptions of an appropriate researcher role and research orientation. These questions may be deemed unattainable with established methods or may be deemed less important.

\subsection{The interface of the MA and OM fields}

The presentation of management accounting in production environments in the OM literature signals expectations on management accounting as a provider of objective information and a lack of such "correct" information is interpreted as a failure. The OM literature thus attempts to provide solutions to problems where MA research has failed. In the OM field, actors are seldom present in the provided solutions. Rather, the provided solutions rest upon rational parameters. The research assumptions characterizing the field of OM puts emphasis on rational solutions, which MA research often are not able to respond to.

Although functionalist research characterizes the MA and OM research fields, the fields differ in terms of orientation. The OM literature takes management accounting for granted to support operational activities, while the MA literature takes a more reflexive role by adapting to new operational practices, a pattern that appears repetitively. The functionalist MA research sees to fulfil some of the OM research requirements by adapting management accounting techniques. The interpretive MA research at times forgets the practical relevance of the research, giving limited practical guidance. Rather than new and/or different accounting procedures adjusted to operational practices, communication between the fields might be needed (Lowe and De Loo 2014) to understand and work with prejudices about the other field. Perhaps we can then overcome the misalignment between research and what is communicated (Saulpic and Zarlowski 2014).

\section{Conclusions}

The thesis of this paper was that via an examination of the interface between the fields of MA and OM regarding paradigms, theories and methods, the understanding of the underlying assumptions upon which the research rests could be enhanced. This literature review highlight nuances in the taken-for-granted assumptions of management 
accounting in production environments. These assumptions may therefore be challenged. Three conclusions, which are complementary rather than competing, can be drawn based on this literature review.

First, the presentation of management accounting in production environments in the literature is too simplistic and needs to be reconsidered in favor of a broader view. It has become a mantra for OM researchers to problematize management accounting in production environments as a starting point for pursuing an OM research agenda.

Second, the expectations on management accounting in production environments need to be considered together with the research intention. Failure to deliver research resting upon simplistic assumptions may not be considered shortcomings in the field of MA. Rather, the ways management accounting is portrayed in the functionalist research, adds to the view of management accounting as meant to respond to OM needs. This conveys a simplified image of management accounting in production environments not fully shared in the MA research field. When the pursuit to fulfill these perceptions fails, the shortcomings of management accounting in production environments seem to become taken-for-granted.

Third, the practical connotation in the fields of MA and OM needs to be considered with the research orientation. The fields do not necessarily have similar understandings of practice. Despite a problem-solving orientation in the OM field, the focus is on concept rather than practice. Little interest is shown in the OM field in researching practicing operational members and their relation to management accounting arrangements. There is also a risk of eliminating something potentially useful for practicing operational members by eliminating management accounting in research models. In addition, the theory orientation in the MA field pursues theoretical contributions rather than practical relevance. In this way, a practical understanding from an OM perspective as well as a practical relevance from a MA perspective may be at risk.

\subsection{Contribution and implications}

Through a comparative overview of the MA and OM literature, this review contributes to the literature by pinpointing how differences in ontological standpoints, stated research questions, terminology, views of management accounting's role in research, the researcher role, and research orientation are discerned as central to the divide between the two fields. This review additionally points out research paths forward that may bring progress for knowledge creation concerning management accounting in production environments.

\subsection{Limitations}

The review is limited to exploring management accounting in production environments as presented in the fields of MA and OM in terms of paradigms, theories, and methods. The empirical differences between the fields are beyond the scope of this paper. In addition to the conclusions presented in the section above, several other aspects might clarify the assumptions of management accounting in production environments, such as country of origin, industry, historical context, and level of analysis. Several articles 
are from the $1990 \mathrm{~s}$ and the oldest in the review was published in 1985. The time aspect complicates the comparison of research. The different eras imply potential differences in ways of thinking and social norms and this has been considered in the literature review process.

\subsection{Final thoughts regarding paths forward}

Paradigms, theories and methods are essential in the interface between MA and OM research as they represent the defining worldview (Guba and Lincoln 1994) of the researcher. The fields seem to pursue research based on assumptions about management accounting in production environments without all too often challenging such assumptions. At stake is the research legitimacy. As OM research aims to push MA research to acknowledge errors in management accounting, the MA literature contributes to the problem in a similar way by not questioning the perceptions that OM researchers have regarding MA research. Approaching the other field with the intention of a more open dialogue may be useful as a path forward. However, this step implies awareness and acceptance (from both fields) that both fields have preconceptions of the other. The challenge for both fields is to question what is taken for granted and realize the potential and restrictions, not to propagandize each field, or the perceptions of management accounting might never be altered. In short, future research could address the perceptions and attitudes regarding management accounting's intended role in production environments via interventionist research.

Understanding of practice stands out as a main divider between the fields, but it might also serve as a bridge. The remaining question is how research results can be communicated across research fields and be taken into consideration by the other field. The lack of understanding between worldviews in this MA and OM research interface is part of the problem of taken-for-granted assumptions. This lack of a functioning and ongoing interface between the fields can have dramatic implications, for example in terms of reinventing the wheel or making only marginal research contributions. Instead, various research studies could contribute with different and specific pieces of a puzzle. The probability of fully being able to grasp one's own pieces may increase through an awareness of puzzle pieces from other research fields. In short, future research could address management accounting understandings by considering and conducting research with different theoretical understandings.

This review reveals interesting questions to address in empirical research, where the fields of MA and OM can learn from each other as well as from the relation between the two. Perhaps learning from each other is not enough; what is needed may be learning together in practice and research. Baxter and Chua (2009) emphasize that research and practice can learn from each other. Methods such as interviews, observations, and shadowing enable researchers to identify problems and ways of working with management accounting that arise in practice, which might not be discovered without these methods. Thus, these methods can be interpreted as evolving management accounting in practice, and at the same time practice can take management accounting research further. Hence, if we approach practice with previously unasked questions, with unconventional methods, and question the taken-for-grantedness of management 
accounting, we may contribute with new knowledge about its use and interpretation on the shop floor. This might be a way forward in empirical management accounting research.

Open Access This article is distributed under the terms of the Creative Commons Attribution 4.0 International License (http://creativecommons.org/licenses/by/4.0/), which permits unrestricted use, distribution, and reproduction in any medium, provided you give appropriate credit to the original author(s) and the source, provide a link to the Creative Commons license, and indicate if changes were made.

\section{References}

Abdel-Maksoud A, Cerbioni F, Ricceri F, Velayutham S (2010) Employee morale, non- financial performance measures, deployment of innovative managerial practices and shop- floor involvement in Italian manufacturing firms. Br Acc Rev 42:36-55

Abernethy MA, Bouwens J (2005) Determinants of accounting innovation implementation. Abacus 41:217-240

Abernethy MA, Horne M, Lillis AM, Malina MA, Selto FH (2005) A multi-method approach to building causal performance maps from expert knowledge. Manag Acc Res 16:135-155

Ahrens T (2008) Overcoming the subjective-objective divide in interpretive management accounting research. Acc Org Soc 33:292-297

Ahrens T, Mollona M (2007) Organisational control as cultural practice-a shop floor ethnography of a Sheffield steel mill. Acc Org Soc 32:305-331

Al-Omiri M, Drury C (2007) A survey of factors influencing the choice of product costing systems in UK organizations. Manag Acc Res 18:399-424

Archel P, Husillos J, Larrinaga C, Spence C (2009) Social disclosure, legitimacy theory and the role of the state. Account Audit Account J 22:1284-1307

Arnold PJ (1999) From the union hall: a labor critique of the new manufacturing and accounting regimes. Crit Perspect Acc 10:399-423

Arya A, Gong N, Ramanan RN (2014) Quality testing and product rationing by input suppliers. Prod Oper Manag 23(11):1835-1844

Bakke NA, Hellberg R (1991) Relevance lost? A critical discussion of different cost accounting principles in connection with decision making for both short and long term production scheduling. Int $\mathrm{J}$ Prod Econ 24:1-18

Baldvinsdottir G, Mitchell F, Nørreklit H (2010) Issues in the relationship between theory and practice in management accounting. Manag Acc Res 21(2):79-82

Banker RD, Datar SM, Kekre S (1988) Relevant costs, congestion and stochasticity in production environments. J Acc Econ 10:171-197

Baxter J, Chua WF (2009) Studying accounting in action: The challenge of engaging with management accounting practice. Accounting, organizations, and institutions: essays in honour of Anthony Hopwood. Oxford University Press, Oxford, pp 65-84

Bendoly E, Rosenzweig ED, Stratman JK (2007) Performance metric portfolios: a framework and empirical analysis. Prod Oper Manag 16:257-276

Berry AJ, Capps T, Cooper D, Ferguson P, Hopper T, Lowe EA (1985) Management control in an area of the NCB: rationales of accounting practices in a public enterprise. Acc Org Soc 10:3-28

Bhimani A (1994) Modern cost management: putting the organization before the technique. Int J Prod Econ 36:29-37

Block J, Fisch C, van Praag M (2017) The Schumpeterian entrepreneur: a review of the empirical evidence on the antecedents, behaviour and consequences of innovative entrepreneurship. Ind Innov 24:61-95

Bourne M, Neely A, Mills J, Platts K (2003) Implementing performance measurement systems: a literature review. Int J Bus Perf Manag 5:1-24

Bromwich M, Bhimani A (1989) Management accounting: evolution not revolution. Chartered Institute of Management Accountants, London

Burrell G, Morgan G (1979) Sociological paradigms and organisational analysis. Heinemann, London

Chang D, Lee SM (1996) The impact of critical success factors of JIT implementation on organizational performance. Prod Plan Control 7:329-338 
Chapman CS (1998) Accountants in organisational networks. Acc Org Soc 23:737-766

Chen CC (2008) An objective-oriented and product-line-based manufacturing performance measurement. Int J Prod Econ 112:380-390

Cooper D (1980) Discussion of towards a political economy of accounting. Acc Organ Soc 5(1):161-166

Corbey M (1994) On the availability of "relevant costs" information in operations management. Int J Prod Econ 35:121-129

Darlington J, Francis M, Found P, Thomas A (2015) Design and implementation of a Drum-Buffer-Rope pull-system. Prod Plann Control 26(6):489-504

Datar S, Kekre S, Mukhopadyay T, Svaan E (1991) Overloaded overheads: activity- based cost analysis of material handling in cell manufacturing. J Oper Manag 10:119-137

Emsley D (2001) Redesigning variance analysis for problem solving. Manag Acc Res 12:21-40

Feak CB, Swales JM (2009) Telling a research story: writing a literature review. University of Michigan Press, Michigan

Filomena TP, Anzanello MJ, Neto FJK, Duffey M, Campos-Nanez E (2011) Manufacturing feature-based cost management system: a case study in brazil. Prod Plan Control 22:414-425

Fisch C, Block J (2018) Six tips for your (systematic) literature review in business and management research. Manag Rev Q 68:103-106

Føllesdal D (1979) Hermeneutics and the hypothetico-deductive method. Dialectica 33:319-336

Fullerton RR, Kennedy FA, Widener SK (2013) Management accounting and control practices in a lean manufacturing environment. Acc Org Soc 38:50-71

Ghalayini AM, Noble JS, Crowe TJ (1997) An integrated dynamic performance measurement system for improving manufacturing competitiveness. Int J Prod Econ 48:207-225

Graf-Vlachy L, Buhtz K, König A (2018) Social influence in technology adoption: taking stock and moving forward. Manag Rev Q 68:37-76

Guba EG, Lincoln YS (1994) Competing paradigms in qualitative research. Handb Qual Res 2(163-194):105

Hall M (2010) Accounting information and managerial work. Acc Org Soc 35:301-315

Hansen A, Mouritsen J (2006) Management accounting and operations management: understanding the challenges from integrated manufacturing. Handb Manag Account Res 2:729-752

Hansen A, Mouritsen J (2007) Management accounting and changing operations management. Issues Manag Account 3:3-25

Hart C (1998) Doing a literature review: releasing the social science research imagination. Sage, Thousand Oaks

Hayes RH, Wheelwright SC (1979) Link manufacturing process and product life cycles. Harvard Bus Rev 57:133-140

H'Mida F, Vernadat F (2009) A constraint approach (flexible CSP) for alternative cost estimation of a mechanical product. Int J Prod Res 47:305-320

Hoque Z, Hopper T (1994) Rationality, accounting and politics: a case study of management control in a Bangladeshi jute mill. Manag Acc Res 5:5-30

Jazayeri M, Hopper T (1999) Management accounting within world class manufacturing: a case study. Manag Acc Res 10(3):263-301

Johnson HT, Kaplan RS (1987) Relevance lost. The Rise and Fall of Management Accounting, Boston

Jönsson S (1998) Relate management accounting research to managerial work! Acc Org Soc 23:411-434

Kihn L, Näsi S (2010) Research strategic analysis of the finnish doctoral dissertations in management accounting from 1990 to 2009. Finn J Bus Econ 1, Forthcoming. Available at SSRN: https://ssrn.co $\mathrm{m} / \mathrm{abstract}=1616170$

Kirche E, Srivastava R (2005) An ABC-based cost model with inventory and order level costs: a comparison with TOC. Int J Prod Res 43:1685-1710

Lange-Ros ED, Boer H (2001) Theory and practice of continuous improvement in shop-floor teams. Int J Tech Manag 22:244-358

Latour B (1987) Science in action: How to follow scientists and engineers through society. Harvard university press

Lin ZJ, Yu Z (2002) Responsibility cost control system in China: a case of management accounting application. Manag Acc Res 13:447-467

Lowe A, de Loo I (2014) The existential perversity of management accounting and control: management control and uncertainty. Springer, Berlin, pp 239-254

Lowe A, Koh B (2007) Inscribing the organization: representations in dispute between accounting and production. Crit Perspect Acc 18:952-974 
Lukka K (2010) The roles and effects of paradigms in accounting research. Manag Acc Res 21:110-115

Lukka K, Mouritsen J (2002) Homogeneity or heterogeneity of research in management accounting? Eur Acc Rev 11:805-811

Macintosh NB (1994) Management accounting and control systems: an organizational and behavioral approach. Wiley, New York

Macintosh NB, Daft RL (1987) Management control systems and departmental interdependencies: an empirical study. Acc Org Soc 12:49-61

Malmi T (2010) Reflections on paradigms in action in accounting research. Manag Acc Res 21:121-123

Maskell BH (2000) Lean accounting for lean manufacturers. Manuf Eng 125:46-53

Melnyk SA, Stewart DM, Swink M (2004) Metrics and performance measurement in operations management: dealing with the metrics maze. J Oper Manag 22:209-218

Merchant KA (2010) Paradigms in accounting research: a view from North America. Manag Acc Res 21(2):116-120

Miles MB, Huberman AM, Huberman MA, Huberman M (1994) Qualitative data analysis: an expanded sourcebook. Sage

Mia L (2000) Just-in-time manufacturing, management accounting systems and profitability. Acc Bus Res 30:137-151

Miller P, O'Leary T (1993) Accounting expertise and the politics of the product: economic citizenship and modes of corporate governance. Acc Org Soc 18:187-206

Modell S (2010) Bridging the paradigm divide in management accounting research: the role of mixed methods approaches. Manag Acc Res 21(2):124-129

Nagar V, Rajan MV, Saouma R (2009) The incentive value of inventory and cross- training in modern manufacturing. J Acc Res 47:991-1025

Ortega CH, Garrido-Vega P, Machuca JAD (2012) Analysis of interaction fit between manufacturing strategy and technology management and its impact on performance. Int J Oper Prod Manag 32:958-981

Otley D (1999) Performance management: a framework for management control systems research. Manag acc res 10:363-382

Paksoy T, Özceylan E, Gökçen H (2012) Supply chain optimisation with assembly line balancing. Int J Prod Res 50:3115-3136

Philipoom PR, Fry TD (1999) Order review/release in the absence of adherence to formal scheduling policies. J Oper Manag 17:327-342

Radnor ZJ, Barnes D (2007) Historical analysis of performance measurement and management in operations management. Int J Prod Perf Manag 56:384-396

Reid GC, Smith JA (2000) The impact of contingencies on management accounting system development. Manag Acc Res 11:427-450

Roberts J, Scapens R (1985) Accounting systems and systems of accountability—understanding accounting practices in their organisational contexts. Acc Org Soc 10:443-456

Saulpic O, Zarlowski P (2014) Management control research and the management of uncertainty: rethinking knowledge in management. Management control and uncertainty. Springer, Berlin, pp 207-223

Scapens RW (2004) Doing case study research. In: Humphrey C, Lee B (eds) The real life guide to accounting research. CIMA Publishing, Oxford, pp 257-279

Schmidt U, Günther T (2016) Public sector accounting research in the higher education sector: a systematic literature review. Manag Rev Q 66:235-265

Shan J, Zhu K (2013) Inventory management in China: an empirical study. Prod Oper Manag 22:302-313

Skinner W (1986) The productivity paradox. Manag Rev 75:41

Spedding TA, Sun GQ (1999) Application of discrete event simulation to the activity based costing of manufacturing systems. Int J Prod Econ 58:289-301

Tayles M, Walley P (1997) Integrating manufacturing and management accounting strategy: case study insights. Int J Prod Econ 53:43-55

Uddin S, Hopper T (2001) A Bangladesh soap opera: privatisation, accounting, and regimes of control in a less developed country. Acc Organ Soc 26(7-8):643-672

Woo J, Kulvatunyou B, Cho H (2008) Allocation of manufacturers through internet- based collaboration for distributed process planning. Int J Prod Res 46:1991-2007 